\title{
STUDY ABROAD EXPERIENCE AND ATTITUDES TOWARDS OTHER NATIONALITIES
}

\author{
Jana Cahlíková
}
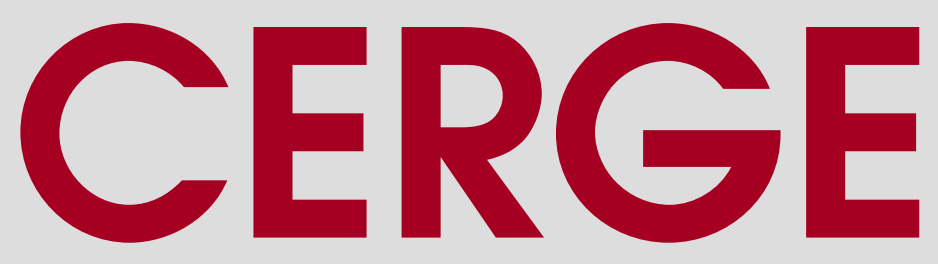


\title{
Working Paper Series 556 (ISSN 1211-3298)
}

\section{Study Abroad Experience and Attitudes Towards Other Nationalities}

\author{
Jana Cahlíková
}

CERGE-EI

Prague, December 2015 
ISBN 978-80-7343-363-5 (Univerzita Karlova v Praze, Centrum pro ekonomický výzkum a doktorské studium)

ISBN 978-80-7344-367-2 (Národohospodářský ústav AV ČR, v. v. i.) 


\title{
Study Abroad Experience and Attitudes Towards Other Nationalities*
}

\author{
Jana Cahlíková ††
}

December 14, 2015

\begin{abstract}
Every year, millions of people relocate to a foreign country for school or work. This paper provides evidence of how international experience shifts preferences and stereotypes related to other nationalities. I use participation in the Erasmus study abroad program to identify the effect of international experience: students who are ready to participate in the Erasmus program are chosen as a control group for students who have returned from studies abroad. Individuals make decisions in a Trust Game and in a Triple Dictator Game. Results show that while students do not differentiate between partners from Northern and Southern Europe in the Trust Game prior to an Erasmus study abroad, students who have returned from Erasmus exhibit less trust towards partners from the South. Behavior towards other nationalities in the Triple Dictator Game is not affected by the Erasmus study experience. Overall, the results suggest that participants learn about cross-country variation in cooperative behavior while abroad and therefore statistical discrimination increases with international experience.
\end{abstract}

JEL codes: C9, D04, J15

Keywords: Discrimination, Inter-group contact, Trust, Identity, Study abroad

*I would like to thank Michal Bauer, Bertil Tungodden, Alexander W. Cappelen, Štěpán Jurajda, Peter Katuščák, Gerard Roland, Avner Shaked and seminar participants at CERGE-EI, Central European University, Max Planck Institute for Tax Law and Public Finance, Norwegian School of Economics, Nova School of Business and Economics, and Wesleyan University for their helpful comments. I also thank Lubomír Cingl, Ian Levely, and Vojtěch Bartoš for their assistance with the experimental data collection. This research was supported by GDN (grant no. RRC 12+46), by the Czech Science Foundation (grant no. P402/12/G130), by the grant SVV-2012-265 801, and by the CEFRES/Komercni banka scholarship. The paper has previously been circulated under the title "Does the Study Abroad Experience Affect Attitudes Towards Other Nationalities?" All errors remaining in this text are the responsibility of the author.

†Max Planck Institute for Tax Law and Public Finance, Department of Public Economics, Marstallplatz 1, 80539 Munich, Germany. Email: jana.cahlikova@tax.mpg.de.

$\ddagger$ CERGE-EI, a joint workplace of Charles University in Prague and the Economics Institute of the Czech Academy of Sciences, Politickych veznu 7, 11121 Prague, Czech Republic. 


\section{Introduction}

Even though millions of people relocate abroad every year to study, work, or for personal reasons, little is known about how such experience affects their attitudes towards other nationalities. On one hand, preferences can change through the creation of affective ties or establishment of a sense of common identity; these would predict a decrease in taste-based discrimination (Becker, 1971). In fact, increased exposure has long been highlighted as a factor that can help attenuate negative attitudes towards other groups. ${ }^{1}$ On the other hand, there is growing literature showing differences in social capital across countries, usually taking interpersonal trust as the primary measure of social capital (Bornhorst, Ichino, Kirchkamp, Schlag, \& Winter, 2010; Buchan, Johnson, \& Croson, 2006; Guiso, Sapienya, \& Zingales, 2009; Holm \& Danielson, 2005; Willinger, Keser, Lohmann, \& Usunier, 2003). ${ }^{2}$ If people learn about these differences while abroad, statistical discrimination (Arrow, 1973, 1998) towards other nationalities can be magnified by international experience.

In this paper, I evaluate the effect of a major program aiming to increase the international experience of its participants: the European Union's Erasmus program. I adopt an experimental approach to study attitudes towards other nationalities, which enables me to investigate the learning channel of international experience. I also investigate the effect of international experience on outgroup bias against foreigners, asking whether international experience shifts the sense of common identity.

The Erasmus program is the largest student-exchange program in the world. In total, over 3 million students have participated since its foundation; currently,

\footnotetext{
${ }^{1}$ This approach is based on the intergroup contact theory (Allport, 1954; Pettigrew, 1998) and has been applied to tackling discrimination based on gender, race, ethnicity and disabilities. Empirical evidence shows that changes towards more positive attitudes are indeed possible (Beaman, Chattopadhyay, Duflo, Pande, \& Topalova, 2009; Boisjoly, Duncan, Kremer, Levy, \& Eccles, 2006; Clingingsmith, Khwaja, \& Kremer, 2009; Dobbie \& Fryer Jr., 2015; Laar, Levin, Sinclair, \& Sidanius, 2005; Pettigrew \& Tropp, 2006).

${ }^{2}$ Willinger et al. (2003) compare trust behavior in Germany and France, Holm and Danielson (2005) Sweden and Tanzania, Buchan et al. (2006) compare the U.S., China, Korea and Japan. Bornhorst et al. (2010) compare European countries, distinguishing between the North and South.
} 
more than 250,000 students participate annually. To avoid many problems due to selection into the program, I compare students who have just returned from their Erasmus stay to successful applicants who are just about to leave for their stay. I use a Trust Game (Berg, Dickhaut, \& McCabe, 1995) as a proxy for a "business-like" interaction in which expectations about a partner's behavior play a major role and a Triple Dictator Game as a measure of non-strategic prosocial motivation, following Fershtman and Gneezy (2001) and Bauer, Fiala, and Levely (2014). A total of 199 students from the Czech Republic participated in the experiment, which took place either before or after their Erasmus stay in other European countries. The experiment required them to interact with partners of their own nationality and with partners from other European countries. As an important advantage over studies based on surveys, behavior was incentivized, and participants did not know that they had been invited into the study because of their past or future participation in the Erasmus program.

The main finding of this paper is that, while students do not differentiate between partners from Northern and Southern Europe in the Trust Game prior to Erasmus study stay, students with Erasmus experience start to exhibit lower trust towards partners from Southern Europe. This discrimination pattern is consistent with the variation in social capital across Europe, and the results overall support the notion that students learn about cross-country differences in cooperative behavior while abroad. In other words, statistical discrimination towards other nationalities seems to become stronger with international experience. As a second finding, Erasmus experience does not shift the bias against foreigners in the Triple Dictator Game, suggesting that the sense of European identity does not increase as a result of the program. However, this is because there is no outgroup bias against foreigners even among students who have not yet studied abroad, plausibly due to (self-) selection.

The existing literature shows that a low level of social capital is linked to the 
efficiency of interpersonal interactions within society (Alesina \& La Ferrara, 2002; Gachter \& Herrmann, 2011; Glaeser, Laibson, Scheinkman, \& Soutter, 2000; Henrich et al., 2001, 2006; Herrmann, Thöni, \& Gächter, 2008), and therefore can hinder economic development (Gorodnichenko \& Roland, 2011; Knack \& Keefer, 1997; Tabellini, 2010). My results suggest that when taking a more globalized perspective, low social capital within a society can create additional barriers to development - as people of other nations learn about the low social capital of a country, cross-border interactions can also be affected, including diplomatic negotiations, and the amount of international trade.

Furthermore, this paper contributes to the discussion around group identity and its stability. Group identity plays a major role in interpersonal interactions(Akerlof \& Kranton, 2000), potentially leading to discrimination against outgroup members. Ingroup favoritism has been identified both among groups created artificially in the laboratory (Charness, Rigotti, \& Rustichini, 2007; Chen \& Li, 2009; Tajfel, Billing, Bundy, \& Flament, 1971) and among real social groups (Bernhard, Fehr, \& Fischbacher, 2006; Goette, Huffman, \& Meier, 2006). Using survey data on trust, Guiso et al. (2009) finds that there is ingroup favoritism towards one's own nationality. Exposure to foreigners could, in principle, help create a sense of common identity - a person may become closer to feeling like a "European" or a "world" citizen. Among policy makers, there is much optimism regarding this channel. ${ }^{3}$ Unfortunately, there is little evidence to support these claims. The main problem is that most studies do not separate the effects of the program from the selection effect. ${ }^{4}$ Selection into

\footnotetext{
${ }^{3}$ The Erasmus program proclaims to be "changing lives, opening minds", and believes that "[T]heir experiences give students a better sense of what it means to be a European citizen." Source: http://europa.eu/youth/article/erasmus-exchange-programme_en

${ }^{4}$ See the literature survey in Di Pietro (2013). The few exceptions focus on labor market outcomes: Parey and Waldinger (2010) and Di Pietro (2013) find a positive effect of a study abroad stay on future international labor mobility and employability, respectively, using a variation in program availability as an instrument for the participation decision. The European Commission has only recently published an evaluation of Erasmus that acknowledges the problem of selection and partially implements an ex-ante/ex-post survey design. See European Commission (2014).
} 
the Erasmus program is an important issue, as under current conditions only about $5 \%$ of all European students participate in the program.

My results suggest that the strength of European identity does not change as a result of Erasmus experience. If there is a shift in the sense of European identity, ingroup favoritism towards one's own nationality should diminish or disappear. But I do not find any bias against other nationalities in the Triple Dictator Game for the students before or after their Erasmus stay. The two samples also respond similarly when asked about the strength of European identity in a questionnaire. In this highly selective environment, students selected for the program seem to feel quite European even before their Erasmus stay. Evaluating the issue of selection further, students in my sample who do not intend to go on Erasmus are more biased against foreign partners and feel less European. Therefore, it seems the popular view that the Erasmus program strengthens the sense of European identity is driven by the selection into the program and not by the effects of the program. Still, the effects of Erasmus estimated in this article should be viewed as the average treatment effect on the treated. Potentially, if the program were able to target students who feel less European to begin with, there would be room for the "common identity building" channel of international experience to operate.

\section{Experimental design}

To identify the effect of international experience on preferences and stereotypes towards other nationalities, the research design consists of an experiment run on specific subject pools that differ in their degree of international experience - students before and after an Erasmus study-abroad stay. This section first describes the sample selection and then presents details of the experiment procedure. 


\subsection{Sample selection}

This paper uses Erasmus program participation as the source of variation in international experience. I use a between-subject design. Successful applicants who were just about to go on their Erasmus stay at the time of the experiment were taken as a control group for students who had just returned from their Erasmus stay. The experiment took place in Prague, the Czech Republic, and the sample selection process can be summarized as follows:

I cooperated with the largest university in the Czech Republic, Charles University in Prague, ${ }^{5}$ and obtained a database of all their students who were enrolled in the Erasmus program in the academic year 2011/12 (1009 students) and in the academic year 2012/13 (923 students). Students from the 2012/13 database were recruited as "Before Erasmus" subjects for sessions that took place in June 2012, while students from the 2011/12 database were recruited as "After Erasmus" subjects for sessions in June 2012 and November 2012. ${ }^{6}$

The email invitation to the experiment did not mention the Erasmus program, but encouraged the recipient to take part in a paid experiment in decision making. The e-mail included a personalized link, which was used for online registration into one of the available sessions. Overall, more slots were opened for the "After Erasmus" students compared to the "Before Erasmus" students and more students from the 2011/12 database were invited, compared to the 2012/13 database. This is because the "After Erasmus" had to be invited to both June 2012 and November 2012 sessions, to allow a control for time effect; see the discussion in section 2.2.

\footnotetext{
${ }^{5}$ Charles University has over 50,000 registered students. It also sends more students to the Erasmus program than any other Czech school; for illustration, 5,589 students from Czech universities participated in the Erasmus program in the academic year 2010/2011. Out of these, almost one fifth $(1,056)$, were from Charles University.

${ }^{6}$ Each of the 2011/12 and 2012/13 populations was divided into thirds using stratified random sampling, with stratification based on gender, study major and the region of the Erasmus stay. Two thirds of each population were invited for participation in the experiments in June 2012; two thirds of the 2011/12 database were invited again in November 2012. This means that one-third of the 2011/12 population was invited twice, however, each subject could participate only once.
} 
The two main samples consist of 75 local students who were about to leave on their Erasmus stay in other European countries ("Before Erasmus" sample) and 124 local students who had already returned from their study-abroad stay ("After Erasmus" sample). ${ }^{7}$ Summary statistics of the "Before Erasmus" and "After Erasmus" samples are presented in Table 1, which shows that the two samples do not differ in characteristics other than age. There is a sufficient variation in terms of age when students go on Erasmus, so age can and will be controlled for in the analysis. ${ }^{8}$

Apart from the two main samples "Before Erasmus" and "After Erasmus", there are two auxiliary samples:

First, the aim is to study behavior towards partners of different nationalities, and to do so without deception. Therefore, international students had to be recruited. Incoming Erasmus students at Charles University were invited by e-mail, and a further recruitment campaign was run on social networks. To ensure sufficient variety of nationalities during the experiment, each session had hidden registration limits for local subjects and international subjects, where the limits were set separately for subjects from Northern and Southern Europe. Overall, 126 international students from Northern and Southern Europe participated in the experiment. ${ }^{9}$

\footnotetext{
${ }^{7}$ Both Czech and Slovak students are perceived as local in the baseline analysis. Slovak students are largely present at Czech universities, due to the lack of a language barrier and cultural proximity. For Charles University, $13.7 \%$ of students are foreigners, of which Slovak students form $46 \%$, according to the 2011 annual report. The results presented in the text are robust to being limited to Czech subjects only. Also, one subject about to go on Erasmus and three subjects with Erasmus experience are neither Czech nor Slovak, but are foreign students doing their degree in Prague and going on Erasmus elsewhere. These subjects are not included in the baseline "Before Erasmus" and "After Erasmus" samples. However, the results presented below are robust to including these subjects.

${ }^{8}$ Furthermore, several robustness checks were performed to make sure the effect of study-abroad stay is estimated, not the effect of age, such as restricting the sample to common support in terms of age. Results are available upon request.

${ }^{9} \mathrm{~A}$ smaller number of slots was opened for students of other nationalities, to avoid suspicion regarding the purpose of the research project during recruitment and during the experiment itself. A total of 38 international students from countries outside Northern and Southern Europe participated in the experiment. As there is no clear prediction regarding changes in behavior of local (Czech and Slovak) students towards subjects from these countries following a study abroad stay in Northern and Southern Europe, these observations are excluded from the analysis. Still, the results presented in the paper are robust to including these observations.
} 
Table 1: Sample characteristics

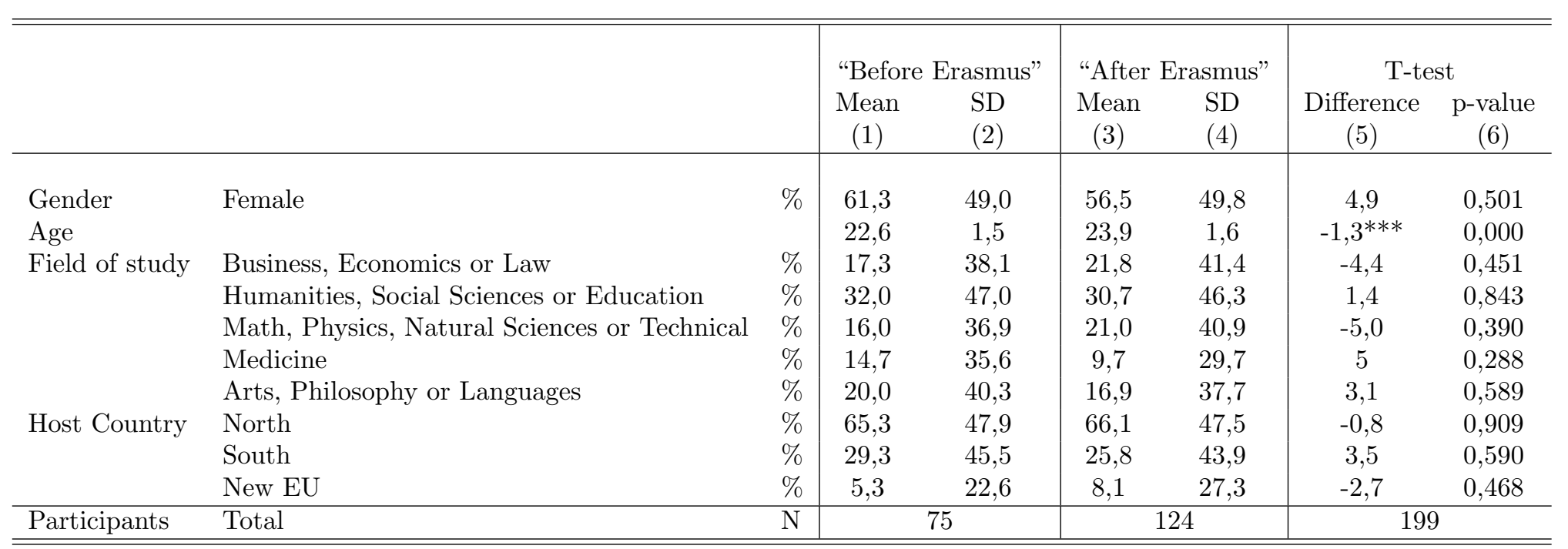

Notes: Means. The table presents characteristics of (Czech and Slovak) subjects before Erasmus study abroad program ("Before Erasmus", Column 1-2) and After Erasmus study abroad ("After Erasmus", Column 3-4). 
Second, a sample of 53 local students with no connection to the Erasmus program ("Never Erasmus" sample) is used to consider selection into the program. These students were recruited through the social network campaign and their Erasmus status was checked using the database of all Erasmus stays in the past years and by asking questions about study-abroad experience in the end-questionnaire.

\section{$2.2 \quad$ Identifying assumptions}

For the identification strategy to hold, three assumptions must be made:

First, the pools of students going on Erasmus in the two consecutive years 2011/12 and 2012/13 must be the same, in terms of baseline attitudes towards other nationalities. In other words, the only difference between the two pools is the realized stay abroad. The Erasmus program did not change between the two academic years, nor did the selection processes. Comparing the observable characteristics of the 2011/12 and 2012/3 databases of all outbound Charles University students, there are no significant differences between the two pools in terms of gender, field of study, or the region of the Erasmus stay (see columns 1 and 2 of Table A.1 in the Appendix). The only difference is that more students in the 2012/13 database were enrolled in a BA-level program at the time of application.

The second assumption is that preferences towards specific nationalities did not change between June 2012, when "Before Erasmus" students participated in the experiment, and November 2012, when most "After Erasmus" students participated. ${ }^{10}$ This is the reason why some "After Erasmus" students were invited into the June 2012 sessions - a robustness check can be run by comparing the two "After Erasmus" subsamples.

Third and most importantly, the experiment participants "After Erasmus" and

\footnotetext{
${ }^{10}$ It was impossible to run all sessions in the same month - many 2011/12 outbound students were not back from their stay by June 2012, while many 2012/13 outbound students would be gone by September 2012.
} 
"Before Erasmus" cannot differ in aspects other than the international experience itself, i.e. recruitment from the 2011/12 and 2012/13 databases of outbound Erasmus students must be equally successful. The recruitment process consisting of e-mail invitations and online registration was described above and was identical for the two pools. Most slots opened for registration were filled and the response rates were similar for the 2011/12 and 2012/13 databases - in respect to the number of experiment participants in relation to the number of invitations sent, the response rates are $11.8 \%$ and $12.1 \%$, respectively. I have already argued that the two samples do not differ in characteristics other than age (see Table 1).

Last but not least, the experiment samples "Before Erasmus" and "After Erasmus" can be compared to all Charles University outbound Erasmus students in the respective years. See Table A.1 in the Appendix. Considering the characteristics available (gender, level of study, field of study, host country), recruitment into the experiment seems to be successful. There are $10 \%$ more males than would be typical in the program, more students of Business, Economics and Law, and fewer students of Medicine. However, these differences can potentially be attributed to the gender limits set in recruitment. ${ }^{11}$ Gender variety was needed for the chosen design which manipulates nationality, gender, and field of study of game partners. The gender limits were more likely to be binding for females, as women form a vast majority (around $70 \%$ ) of all Erasmus program participants.

\section{$2.3 \quad$ Experimental procedure}

Seventeen experiment sessions were organized (nine in June 2012 and eight in November 2013), with the number of subjects per session ranging from 20 to 28 . All sessions took place at the Laboratory of Experimental Economics in Prague. Each session consisted of an introduction in which participants recorded their national-

\footnotetext{
${ }^{11}$ The gender ratio in the experimental sessions could not exceed two thirds in either direction.
} 
ity, gender, age and study major, followed by the main section in which the Triple Dictator Game and the Trust Game were played in a randomized order, of a payoff stage where the individual payoffs were determined, and of an end-questionnaire that focused primarily on the past international experience of the subjects. The experiment was programmed and conducted using the software z-TREE (Fischbacher, 2007).

Participants received written instructions before each stage of the experiment. All payoffs were stated in experimental currency units (ECU). Participants did not receive any feedback on their performance or payoff until the final stage, where they randomly (by hitting buttons on the screen) selected decisions relevant for payment. The experiment lasted on average 2 hours and the average payment was $457 \mathrm{CZK}$ (approximately 18 EUR). ${ }^{12}$

It is important to note that subjects' Erasmus program (past or future) participation was not mentioned in the invitation or at any point during the experiment. ${ }^{13}$

\subsubsection{Experimental tasks}

In the Trust Game, Player A ("Sender") had an endowment of 100 points, while Player B ("Receiver") had an endowment of 0 . In the first stage, Player A decided whether and how much s/he wished to transfer to Player B, choosing between 0, 20, 40, 60, 80 and 100 points. The amount sent was tripled. In the second stage, Player B decided how many points s/he wanted to send back to Player A for any amount potentially sent by Player A, i.e. a strategy method was used. The structure of the game was common knowledge. In addition to actions, beliefs were also elicited. Specifically, these were Player A's first-order and second-order beliefs and Player

\footnotetext{
${ }^{12}$ Student wages in Prague are around 3-4 EUR/hour on average.

${ }^{13}$ At the end of the experiment, students were asked to state the perceived purpose of the study. Erasmus program participation was not mentioned by any subject.
} 
B's first order beliefs. ${ }^{14}$

The structure of the Triple Dictator Game is similar to the Trust Game, except that there is no second stage. Player A decided whether and how much s/he wished to transfer to Player B, choosing between $0,20,40,60,80$ and 100 points and the amount sent was tripled. However, Player B was only a passive receiver of Player A's points and did not make any active decisions. S/he was asked to report only his/her first-order beliefs, i.e. how much s/he thought Player A would send. Player A's second-order beliefs were also elicited.

Each subject played both roles, Player A and B. The order of roles was randomized across sessions, and subjects learned of the existence of the second part only after they finished their decisions in the first role.

\subsubsection{Manipulating a partner's characteristics}

The identity of partners was varied on a within-subject level. In each game, Player A was asked to make decisions about sixteen potential Player Bs. Each partner was characterized by a profile stating nationality, gender, age, and field of study. ${ }^{15}$ Analogously, Player B was asked to make decisions regarding sixteen potential Player As. The decision maker always saw four profiles of potential partners at once and played four of these rounds. To determine the composition of partners' profiles in a given round, session participants were randomly matched in groups of four and one hypothetical profile was added. ${ }^{16}$ The profiles were displayed in a random order.

\footnotetext{
${ }^{14}$ How much Player A thinks B will return for the amount actually sent, how much Player A thinks B expects from him, and how much Player B expects from A, respectively. Subjects receive a bonus of 20 points if they guess correctly. One round is chosen randomly for the payment on beliefs and one partner from that round is relevant for payment.

${ }^{15}$ Participants were asked to provide nationality, gender, age, and field of study at the beginning of the experiment and knew this information would be displayed to the decision makers. Five categories were distinguished with respect to field of study: Business, Economics or Law; Humanities, Social Sciences or Education; Math, Physics, Natural Sciences or Technical; Medicine; Arts, Philosophy and Languages.

${ }^{16}$ The hypothetical profile, which was the same for all subjects in a given round, was added to ensure enough variation in partner profiles. No deception was involved as players were always
} 
One of the sixteen decisions in each role was relevant for payment.

In this paper, a partner's nationality is of primary interest. Additional information was used to decrease the risk of an experimenter-demand effect (Bardsley, 2005), while ensuring that nationality was sufficiently salient. Limits set during the registration process ensured enough variation in nationalities and gender within each session.

The Trust Game was applied in the above setting to study how trust behavior is influenced by the partner's nationality. Behavior in the Triple Dictator Game can be used as a measure of non-strategic prosocial preferences, jointly capturing preferences for altruism, inequality aversion, and efficiency maximization. Therefore, observing behavior in the Triple Dictator Game can help to disentangle preferencebased and beliefs-based components of trust.

\section{Results}

\subsection{Learning channel of international experience}

I first explore whether students learn about cross-country differences in values and behavior while abroad. To test this "learning channel", I examine how senders before and after an Erasmus stay differentiate between partners from Northern and Southern Europe. The choice of these two regions is motivated by the variation in social capital across Europe. Focusing on interpersonal trust as the principle measure of social capital, people from Southern Europe are much less likely to state that other people can be trusted, compared to people from Northern Europe; see Figure $1 .^{17}$ I hypothesize that with a study abroad experience, students learn

asked to state their decisions for all four potential partners they could see, but knew that they would be matched with only one of the four.

${ }^{17}$ Data from the World Values Survey (WVS) are used. The Figure summarizes answers to the WVS question "Generally speaking, would you say that most people can be trusted or that you 
Figure 1: Differences in interpersonal trust across Europe
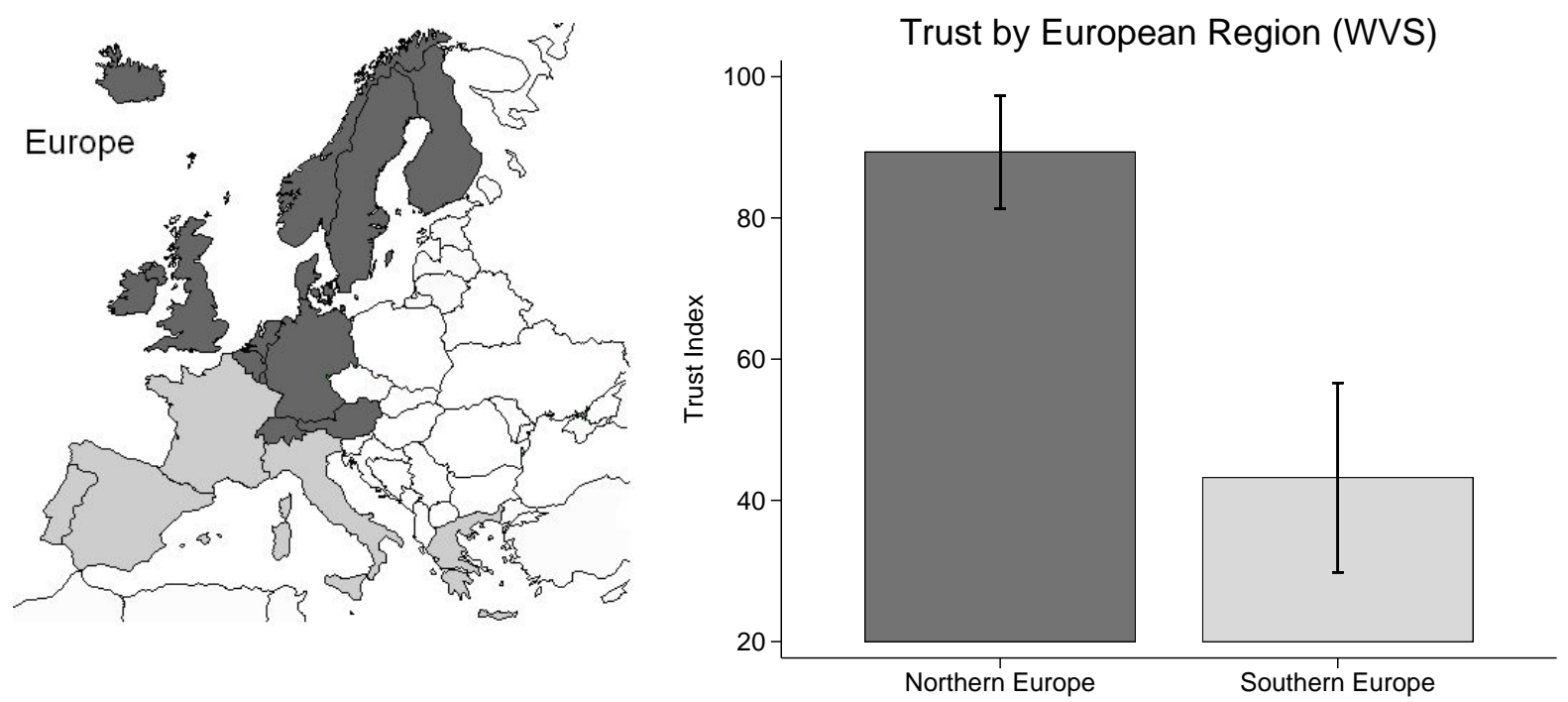

Notes: The Figure summarizes answers to the World Values Survey question "Generally speaking, would you say that most people can be trusted or that you need to be very careful in dealing with people?" (Data Source: ASEP/JDS). Bars indicate mean \pm standard error.

about differences in social capital across Europe and start to differentiate more between partners from Northern and Southern Europe. This effect should be more pronounced in the Trust Game, where a partners' behavior actually matters. The division of countries into Northern and Southern Europe as used in the analysis is presented in Table 2.

\subsubsection{Trust Game - partners from Northern vs. Southern Europe}

Mean behavior in the Trust Game by the Erasmus status of the sender and by the nationality of the receiver is presented in Panel A of Table 3. I will focus on discussing the average amounts sent towards partners from Northern and Southern Europe, where I have a clear prediction regarding the direction of the change due to learning. Senders "Before Erasmus" sent on average 56.9 points to partners

need to be very careful in dealing with people?" See Appendix Figure A.1 for a more detailed map of trust across European countries. 
Table 2: Classification of countries used in the analysis

\begin{tabular}{l|l|l}
\hline \hline \multirow{2}{*}{ "Local" } & \multicolumn{2}{|c}{ "Foreign" } \\
& "North" & "South" \\
\hline \multirow{2}{*}{ Czech Rep. } & Austria & France \\
Slovakia & Belgium & Greece \\
& UK & Italy \\
& Netherlands & Portugal \\
Germany & Spain \\
& Ireland & \\
& & \\
& & \\
& & \\
\hline \hline
\end{tabular}

Notes: Only countries of origin for at least one participant in the experiment are listed.

from the North and 60.1 points to partners from the South. This means that they felt actually more favorable towards Southern receivers, but the difference is not significant (Wilcoxon rank-sum test, $p=0.321$ ). Senders "After Erasmus", on the other hand, sent significantly more points to Northern partners than to Southern partners (58.1 vs. 52.8 points, $p=0.029)$. Put differently, while subjects from Northern Europe received similar amounts from senders before and after Erasmus $(p=0.652)$, subjects from Southern Europe received significantly lower amounts from senders with more international experience $(p=0.019)$.

So far, the results have shown that students "Before Erasmus" do not discriminate between partners from Northern and Southern Europe, while students "After Erasmus" do. Next, I test whether the discrimination pattern changes with a study abroad experience, using a regression analysis. 
Table 3: Means, across experimental manipulations

\begin{tabular}{|c|c|c|c|}
\hline & $\overline{(1)}$ & 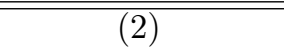 & 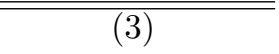 \\
\hline \multicolumn{4}{|c|}{ Panel A: Amount sent in the Trust Game } \\
\hline Sample & $\begin{array}{c}\text { Senders } \\
\text { "Before Erasmus" }\end{array}$ & $\begin{array}{c}\text { Senders } \\
\text { "After Erasmus" }\end{array}$ & $\begin{array}{l}\text { P.p. Diff }(2)-(1) \\
\text { (p-value) }\end{array}$ \\
\hline Receiver Local & 58.1 & 58.9 & $0.8(0.677)$ \\
\hline Receiver Foreign & 58.3 & 55.6 & $-2.7(0.197)$ \\
\hline Receiver North & 56.9 & 58.1 & $1.1(0.652)$ \\
\hline Receiver South & 60.1 & 52.8 & $-7.3(0.019)$ \\
\hline P.p. diff Local-Foreign ( $\mathrm{p}$-value) & $-0.2(0.977)$ & $3.3(0.056)$ & \\
\hline $\mathrm{N}$ & 1,111 & 1,834 & \\
\hline P.p. diff North-South (p-value) & $-3.1(0.321)$ & $5.3(0.029)$ & \\
\hline $\mathrm{N}$ & 523 & 989 & \\
\hline \multicolumn{4}{|c|}{ Panel B: Amount sent in the Triple Dictator Game } \\
\hline Sample & $\begin{array}{c}\text { Senders } \\
\text { "Before Erasmus" }\end{array}$ & $\begin{array}{c}\text { Senders } \\
\text { "After Erasmus" }\end{array}$ & $\begin{array}{c}\text { P.p. Diff (2)-(1) } \\
\text { (p-value) }\end{array}$ \\
\hline Receiver Local & 30.6 & 27.2 & $-3.4(0.075)$ \\
\hline Receiver Foreign & 29.4 & 25.3 & $-4.1(0.004)$ \\
\hline Receiver North & 28.0 & 26.0 & $-2.0(0.285)$ \\
\hline Receiver South & 31.3 & 24.4 & $-6.8(0.002)$ \\
\hline P.p. diff Local-Foreign ( $p$-value) & $1.2(0.829)$ & $1.9(0.154)$ & \\
\hline $\mathrm{N}$ & 1,111 & 1,834 & \\
\hline P.p. diff North-South (p-value) & $-3.2(0.131)$ & $1.6(0.506)$ & \\
\hline $\mathrm{N}$ & 523 & 989 & \\
\hline \multicolumn{4}{|c|}{$\begin{array}{l}\text { Notes: Means. Panel A reports amounts sent in the Trust Game, while Panel B reports } \\
\text { amounts sent in the Triple Dictator game. The Table presents behavior of senders (Czech } \\
\text { and Slovak) before ("Before Erasmus", column 1) and after Erasmus study abroad ("After } \\
\text { Erasmus", column 2), by the nationality of the receiver. See Table } 2 \text { for the classification } \\
\text { of countries into "North", "South", "Local" and "Foreign". All differences are presented in } \\
\text { percentage points and tested using a Wilcoxon rank-sum test. }\end{array}$} \\
\hline
\end{tabular}

The following regression model is estimated:

$$
\begin{array}{r}
\text { AmountSent }_{i, j}^{T G}=\alpha+\beta \text { AfterErasmus } \\
i, j \\
+\gamma \text { RecipientSout }_{i, j} \\
+ \text { RecipientSouth }_{i, j} * \text { AfterErasmus }_{i, j}+X_{i, j}^{\prime} \theta+\varepsilon_{i, j}
\end{array}
$$

, where AmountSent $t_{i, j}^{T G}$ is the amount of points sent in the Trust Game by sender $i$ to receiver $j$. The Erasmus status of the sender is captured by an indicator variable AfterErasmus ${ }_{i, j}$ and the nationality of the receiver by an indi- 
cator variable RecipientSouth ${ }_{i, j}$. The baseline is therefore the amount sent by senders "Before Erasmus" to partners from Northern Europe. Vector $X_{i, j}$ consists of a range of other control variables described below. The interaction term RecipientSouth $_{i, j} *$ AfterErasmus $_{i, j}$ is of primary interest. The coefficient $\delta$ captures how the discrimination pattern between Northern and Southern partners changes as a result of Erasmus program participation. Standard errors are clustered on the sender level.

Estimation results are presented in Table 4 and confirm that discrimination between Northern and Southern partners changes significantly with a study abroad experience - the negative effect of Erasmus stay on the amount sent is specific for Southern partners (column 1, $p=0.044$ ). This result holds when controlling for other senders' and receivers' characteristics observable through the games (gender, age, field of study), for the order of the two games (Trust Game, Triple Dictator Game), and for the order of the two roles (sender, receiver); see columns 2-3 of Table 4 .

Result 1: An Erasmus study abroad stay changes how students discriminate between partners from Northern and Southern Europe in the Trust Game. While students prior to Erasmus study abroad do not differentiate between partners from the two regions, students with study abroad experience send lower amounts to partners from Southern Europe.

I next perform three robustness checks with respect to Result 1:

First, Equation 1 is estimated using ordered probit instead of OLS, to take into account the discrete nature of the dependent variable. Estimation results are presented in Appendix Table A.2. Students after an Erasmus study abroad are significantly less likely to send 100 and 80 points to Southern partners, and more likely to send 0, 20, and 40 points to Southern partners, confirming that there is a negative effect of Erasmus program participation on behavior towards Southern 
Table 4: Trust Game - Effects of Erasmus study abroad on behavior towards partners from Northern and Southern Europe

\begin{tabular}{|c|c|c|c|c|c|c|}
\hline \multirow[t]{2}{*}{$\begin{array}{l}\text { Dependent variable } \\
\text { Sample }\end{array}$} & \multicolumn{6}{|c|}{$\begin{array}{l}\text { Amount sent in the Trust Game } \\
\text { "Before Erasmus" and "After Erasmus" }\end{array}$} \\
\hline & $(1)$ & $(2)$ & (3) & (4) & (5) & (6) \\
\hline After Erasmus & $\begin{array}{c}1.12 \\
(5.36)\end{array}$ & $\begin{array}{l}-1.77 \\
(5.56)\end{array}$ & $\begin{array}{l}-1.87 \\
(5.55)\end{array}$ & $\begin{array}{c}2.05 \\
(4.78)\end{array}$ & $\begin{array}{c}0.98 \\
(5.07)\end{array}$ & $\begin{array}{c}0.91 \\
(5.12)\end{array}$ \\
\hline Receiver South & $\begin{array}{c}3.15 \\
(3.62)\end{array}$ & $\begin{array}{c}3.57 \\
(3.45)\end{array}$ & $\begin{array}{c}3.18 \\
(3.37)\end{array}$ & $\begin{array}{c}1.90 \\
(3.16)\end{array}$ & $\begin{array}{c}2.51 \\
(3.10)\end{array}$ & $\begin{array}{l}1.91 \\
(2.97)\end{array}$ \\
\hline Receiver South*After Erasmus & $\begin{array}{c}-8.46^{* *} \\
(4.18)\end{array}$ & $\begin{array}{c}-9.11^{* *} \\
(4.10)\end{array}$ & $\begin{array}{c}-8.54^{* *} \\
(4.07)\end{array}$ & $\begin{array}{r}-6.53^{*} \\
(3.75)\end{array}$ & $\begin{array}{r}-7.07^{*} \\
(3.77)\end{array}$ & $\begin{array}{l}-6.22^{*} \\
(3.70)\end{array}$ \\
\hline Amount sent in the Triple DG & & & & $\begin{array}{c}0.43^{* * *} \\
(0.05)\end{array}$ & $\begin{array}{c}0.42^{* * *} \\
(0.06)\end{array}$ & $\begin{array}{c}0.43^{* * *} \\
(0.06)\end{array}$ \\
\hline Constant & $\begin{array}{c}56.94^{* * *} \\
(4.34)\end{array}$ & & & $\begin{array}{c}44.86^{* * *} \\
(4.37)\end{array}$ & & \\
\hline Sender's gender, age, study major & & yes & yes & & yes & yes \\
\hline Receiver's gender, age, study major & & yes & yes & & yes & yes \\
\hline Order of the games, roles & & & yes & & & yes \\
\hline Observations & 1,512 & 1,512 & 1,512 & 1,512 & 1,512 & 1,512 \\
\hline
\end{tabular}

Notes: OLS, standard errors are clustered on the sender level. ${ }^{*} \mathrm{p}<0.10,{ }^{* *} \mathrm{p}<0.05,{ }^{* * *} \mathrm{p}<0.01$. Estimation sample are (Czech and Slovak) subjects before and after Erasmus study abroad. Dummy variable "After Erasmus" is equal to one for subjects after and zero for those before Erasmus program. Dummy variable "Receiver South" is equal to one if the receiver comes from Southern Europe and zero for receivers from Northern Europe. See Table 2 for the classification of countries into "North" and "South". In Columns 1-6, the omitted group are decisions of subjects "Before Erasmus" towards receivers from Northern Europe.

partners.

Second, I add behavior towards local (Czech and Slovak) partners into the picture. As is visible from Table 3, behavior towards local partners in the Trust Game is not affected by an Erasmus stay abroad (Wilcoxon rank-sum test, $p=0.677$ ). Therefore, an Erasmus stay has a negative impact only on behavior towards partners from Southern Europe, while it does not affect behavior towards local partners or partners from Northern Europe. In other words, while subjects before an Erasmus study abroad did not differentiate at all based on a partner's nationality in the Trust Game, subjects after an Erasmus study abroad behave less favorably towards partners from Southern Europe, compared to local partners or compared to partners from Northern Europe. 
Third, I run a check showing that the estimated effect is not driven by changed preferences/beliefs regarding Southern partners between June 2012 (when "Before Erasmus" students participated in the experiment) and November 2012 (when most "After Erasmus" students participated). Appendix Figure A.2 presents how senders differentiate between partners from Northern and Southern Europe, splitting the "After Erasmus" sample into June 2012 and November 2012 participants. If anything, the negative effect towards Southern partners is stronger among "After Erasmus" subjects who participated in June 2012.

\subsubsection{Effect by the region of Erasmus study abroad}

It is important to note that students going on Erasmus necessarily meet people from both Northern and Southern Europe, regardless of where they go. However, the learning effect of international experience can still differ by the region of the study abroad stay. I investigate this possibility by re-estimating the effect of Erasmus experience on behavior in the Trust Game separately for students with a (planned or realized) Erasmus stay in Northern Europe and separately for students with an Erasmus stay in the South.

Regression results are presented in Table 5 . The effect goes in the same direction for students going abroad to Northern and Southern Europe, but the strength of the effect and the underlying story differ. Subjects going "North" (column 2-4 of Table 5) do not differentiate between partners from Northern and Southern Europe before their Erasmus stay, but they send significantly less to partners from the South after their stay $(p=0.031)$. The effect of Erasmus on discrimination between Northern and Southern partners, as captured by the variable AfterErasmus* ReceiverSouth, is negative, not significant when focusing on this subgroup separately $(p=0.271)$. 
Table 5: Trust Game - Effects of Erasmus study abroad, by the region of the Erasmus stay

\begin{tabular}{|c|c|c|c|c|c|c|c|}
\hline \multirow{3}{*}{$\begin{array}{l}\text { Dependent variable } \\
\text { Sample } \\
\text { VARIABLES } \\
\end{array}$} & \multicolumn{7}{|c|}{ Amount sent in the Trust game } \\
\hline & \multirow{2}{*}{$\begin{array}{c}\text { All } \\
\text { Senders } \\
\text { "Before" and } \\
\text { "After Erasmus" } \\
(1)\end{array}$} & \multicolumn{3}{|c|}{ Stay North } & \multicolumn{3}{|c|}{ Stay South } \\
\hline & & $\begin{array}{c}\text { Senders } \\
\text { "Before" and } \\
\text { "After Erasmus" } \\
(2)\end{array}$ & $\begin{array}{l}\text { Senders } \\
\text { "Before } \\
\text { Erasmus" } \\
(3)\end{array}$ & $\begin{array}{l}\text { Senders } \\
\text { "After } \\
\text { Erasmus" } \\
(4)\end{array}$ & $\begin{array}{c}\text { Senders } \\
\text { "Before" and } \\
\text { "After Erasmus" } \\
(5)\end{array}$ & $\begin{array}{l}\text { Senders } \\
\text { "Before } \\
\text { Erasmus" } \\
(6)\end{array}$ & $\begin{array}{c}\text { Senders } \\
\text { "After } \\
\text { Erasmus" } \\
\quad(7)\end{array}$ \\
\hline After Erasmus & $\begin{array}{c}1.12 \\
(5.36)\end{array}$ & $\begin{array}{l}-4.15 \\
(6.68)\end{array}$ & & & $\begin{array}{c}9.77 \\
(9.59)\end{array}$ & & \\
\hline Receiver South & $\begin{array}{l}3.15 \\
(3.62)\end{array}$ & $\begin{array}{c}0.04 \\
(4.45)\end{array}$ & $\begin{array}{c}0.04 \\
(4.48)\end{array}$ & $\begin{array}{c}-5.64^{* *} \\
(2.57)\end{array}$ & $\begin{array}{l}11.64^{*} \\
(6.86)\end{array}$ & $\begin{array}{l}11.64 \\
(6.95)\end{array}$ & $\begin{array}{l}-3.45 \\
(4.43)\end{array}$ \\
\hline After Erasmus*Receiver South & $\begin{array}{c}-8.46^{* *} \\
(4.18)\end{array}$ & $\begin{array}{l}-5.68 \\
(5.14)\end{array}$ & & & $\begin{array}{c}-15.09^{*} \\
(8.15)\end{array}$ & & \\
\hline Constant & $\begin{array}{c}56.94^{* * *} \\
(4.34)\end{array}$ & $\begin{array}{c}61.59^{* * *} \\
(5.39)\end{array}$ & $\begin{array}{c}61.59^{* * *} \\
(5.42)\end{array}$ & $\begin{array}{c}57.44^{* * *} \\
(3.96)\end{array}$ & $\begin{array}{c}46.29^{* * *} \\
(7.46)\end{array}$ & $\begin{array}{c}46.29^{* * *} \\
(7.56)\end{array}$ & $\begin{array}{c}56.06^{* * *} \\
(6.06)\end{array}$ \\
\hline Observations & 1,512 & 1,010 & 348 & 662 & 403 & 147 & 256 \\
\hline
\end{tabular}

Notes: OLS, standard errors are clustered on the sender level. ${ }^{*} \mathrm{p}<0.10,{ }^{* *} \mathrm{p}<0.05,{ }^{* * *} \mathrm{p}<0.01$. Estimation sample are (Czech and Slovak) subjects before and after Erasmus study abroad. Columns 2-4 analyse behavior of subjects with planned or realized stay in Northern Europe, while Columns 5-7 focus on subjects going to Southern Europe. Dummy variable "After Erasmus" is equal to one for subjects after and zero for those before Erasmus program. Dummy variable "Receiver South" is equal to one if the receiver comes from Southern Europe and zero for receivers from Northern Europe. See Table 2 for the classification of countries into "North" and "South". In Columns 1,2,5, the omitted group are decisions of subjects "Before Erasmus" towards receivers from Northern Europe. In Columns 3-4 and 6-7, the omitted group are decisions towards receivers from Northern Europe. 
Subjects going "South" (column 5-7 of Table 5) show a strong preferential treatment of partners from Southern Europe before the Erasmus stay, suggesting selfselection in terms of where students decide to go - holding a positive image of Southern Europe, the students decide to go "South". Erasmus study abroad experience then changes dramatically how students differentiate between partners from Northern and Southern Europe. Students with Erasmus experience show higher trust towards partners from Northern Europe, even though this difference is not significant. The change in discrimination pattern with Erasmus, as captured by the variable AfterErasmus $*$ ReceiverSouth, is strong and significant $(p=0.070)$. In terms of effect size, students with experience in Southern Europe are driving the overall negative effect of Erasmus on trust towards Southern partners.

\subsubsection{Beliefs about partners from Northern vs. Southern Europe}

To attribute the observed changes in relative behavior towards partners from Northern and Southern Europe to learning about differences in social capital across countries, I next examine the two measures of beliefs elicited during the experiment.

First, I focus on beliefs about expected trustworthiness, defined as expected amount returned by the receiver, in $\%$ of what was sent to the receiver. Note that the measure of expected trustworthiness is potentially problematic as senders were asked how much they think Player B would return only for the amount that was actually sent. As subjects "After Erasmus" actually sent lower amounts to partners from the "South", the expected trustworthiness is elicited for amounts sent that were on average lower (plus beliefs about trustworthiness are not elicited for subjects who sent 0 points to the receiver). Still, as Panel A of Figure 2 shows, beliefs about trustworthiness of Northern versus Southern partners move in the direction that corresponds to the change observed in the Trust Game, but the beliefs are quite noisy and the change is not statistically significant $(p=0.374)$. 
Figure 2: Effect of an Erasmus study abroad stay on beliefs about trustworthiness and trust of Northern versus Southern partners

Panel A: Beliefs about trustworthiness

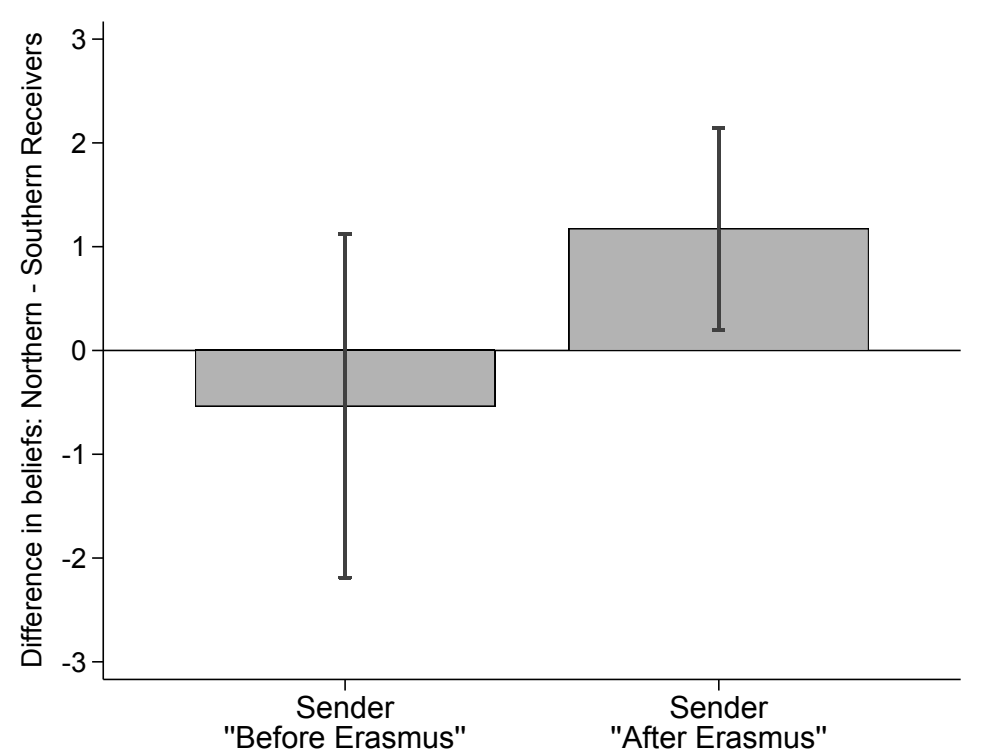

Panel B: Beliefs about trust

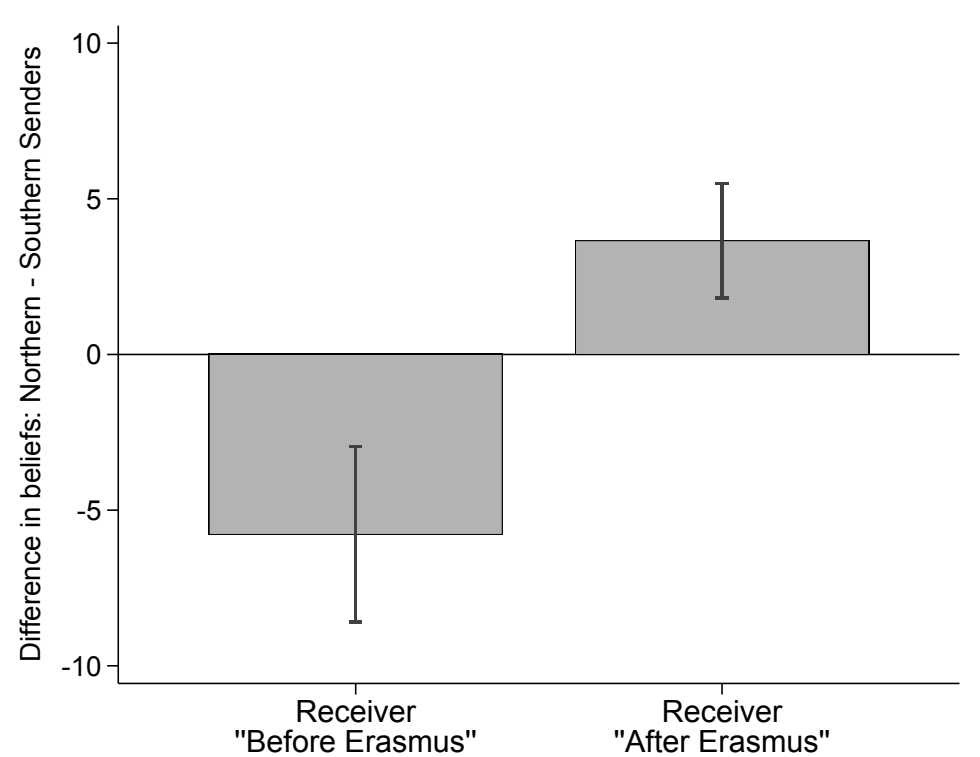

Notes: Panel (a) captures senders' beliefs about the amount returned by Northern vs. Southern receivers in the Trust Game (as $\%$ of what the partner received from the sender), disentangled by whether the subjects are about to leave on a study abroad stay (Sender "Before Erasmus") or have just returned from a study abroad stay (Sender "After Erasmus"). Panel (b) summarizes beliefs about the number of points received from Northern vs. Southern senders in the Trust Game, disentangled by the Erasmus status of the receiver. See Table 2 for the classification of countries into "North" and "South". Bars indicate mean \pm standard error. 
As a cleaner measure of a change in beliefs, I next examine beliefs about trust behavior of senders from Northern and Southern Europe. ${ }^{18} 19$

The effect of Erasmus on beliefs about partners' trust behavior is presented in Panel B of Figure 2. The change in beliefs about trust mirrors the effect found for the beliefs about trustworthiness (Panel A), but the effect is stronger and statistically significant $(p=0.005)$. While subjects "Before Erasmus" expect senders from Southern Europe to send more in the Trust Game compared to Northern senders, subjects "After Erasmus" expect senders from Southern Europe to be less trusting than Northern senders. The latter pattern is consistent with the map of interpersonal trust across Europe shown in Figure 1. Results from regression analysis are presented in Appendix Table A.3 and confirm that the change in beliefs regarding trust behavior of Southern partners is large and statistically significant even when controlling for the observable characteristics of senders and receivers, and for order effects.

\subsubsection{Triple DG - partners from Northern vs. Southern Europe}

Amounts sent in the Triple Dictator Game are presented in Panel B of Table 3. While "Before Erasmus" students treat Southern partners more favorably than Northern partners in the Triple Dictator Game (sending 31.3 vs. 28 points to the two groups, $p=0.131$, Wilcoxon rank-sum test), this difference disappears after Erasmus study abroad. Students "After Erasmus" actually send more points to Northern partners,

\footnotetext{
${ }^{18}$ Beliefs about points received from these senders in the Trust Game from the position of local receivers before or after their Erasmus stay.

${ }^{19}$ Trust and trustworthiness behavior are closely linked. When considering individual-level behavior in my sample, trust and trustworthiness behavior is significantly correlated, both for the local students (Spearman's rank correlation, $\rho=0.4570, p<0.001$ ) and for foreigners from Northern and Southern Europe $(\rho=0.4682, p<0.001$. Appendix Figure A.3 summarizes this result graphically. As a measure of an individual's trust level, I computed the average amount sent in the Trust Game, averaging over the 16 profiles of potential partners. As a measure of an individual's trustworthiness, I computed average return ratio (Return ratio= amount returned to sender $/\left(3^{*}\right.$ amount sent by sender $)$, averaging over all receiver's decisions. Each receiver makes 80 trustworthiness decisions - for 16 profiles of potential senders and 5 trustworthiness decisions per sender, as receiver's decisions were elicited using the strategy method.
} 
Table 6: Triple Dictator Game - Effects of Erasmus study abroad on behavior towards partners from Northern and Southern Europe

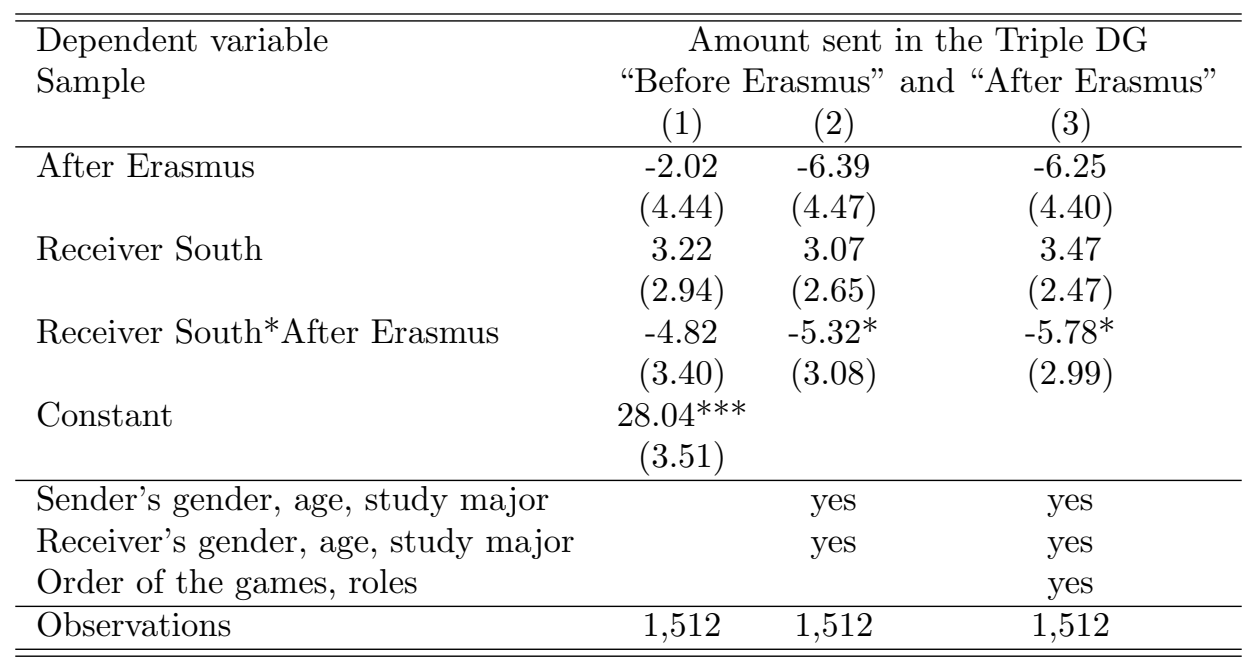

Notes: OLS, standard errors are clustered on the sender level.* $\mathrm{p}<0.10,{ }^{* *}$ $\mathrm{p}<0.05,{ }^{* * *} \mathrm{p}<0.01$. Estimation sample are (Czech and Slovak) subjects before and after Erasmus study abroad. Dummy variable "After Erasmus" is equal to one for subjects after and zero for those before Erasmus program. Dummy variable "Receiver South" is equal to one if the receiver comes from Southern Europe and zero for receivers from Northern Europe. See Table 2 for the classification of countries into "North" and "South". In Columns 1-3, the omitted group are decisions of subjects "Before Erasmus" towards receivers from Northern Europe.

but the difference is small and insignificant ( 24.4 points vs. 26 points, $p=0.506$ ).

Estimation results then show that an Erasmus stay has a negative impact on the amount sent to Southern partners relative to Northern partners (column 1 of Table 6), but the effect is significant at $10 \%$ level only when controlling for additional characteristics (columns 2-3). The effect thus goes in the same direction as the effect in the Trust Game, but is weaker. More importantly, when adding local partners to the picture, it is clear that the negative effect of Erasmus on the amount sent in the Triple Dictator Game is not unique to receivers from Southern Europe (see Panel B of Table 3). Rather, there is a general negative effect of Erasmus program participation on the amount sent in the Triple Dictator Game and the response does not significantly differ between local and Southern or Northern partners, as shown in Table 7 (columns 4-6). This is in comparison to the behavior in the Trust Game, 
where the negative effect of the Erasmus program participation was observed only for partners from Southern Europe.

Behavior in the Triple Dictator Game can be used to measure non-strategic prosocial motivations towards partners from Northern and Southern Europe. As these motives can be present also in the Trust Game, I want to test whether the observed changes in the Trust Game are caused by the preference-based component of trust or the beliefs-based component of trust. This is done by re-estimating the effect of Erasmus on discrimination between Northern and Southern partners in the Trust Game, this time controlling for behavior towards these partners in the Triple Dictator Game.

Estimation results are present in columns 4-6 of Table 4. The negative effect of Erasmus study abroad on behavior specifically towards partners from Southern Europe in the Trust Game persists even when controlling for the behavior in the Triple Dictator Game. These results suggest that the differentiation between partners from Northern and Southern Europe in the Trust Game among subjects with study abroad experience (as presented in Panel A of Table 3) cannot be explained by differences in the preference-based, non-strategic component of trust. ${ }^{20}$

\subsubsection{Discussion}

Overall, results from this section show that students with international experience start to differentiate between partners from Northern and Southern Europe. Presumably, this effect is driven by learning about behavioral differences across regions

\footnotetext{
${ }^{20}$ Note that the behavior in the Triple Dictator Game is significantly correlated with the behavior in the Trust Game $(p<0.01)$, but the estimated coefficient is significantly below 1 . Specifically, the point estimate lies between 0.4 and 0.5 for all samples of local (Czech and Slovak) students - those "Before Erasmus", "After Erasmus" and also for Erasmus non-participants ("Never Erasmus"); detailed results available upon request. Moreover, I cannot reject the null hypothesis that the coefficient is the same across the three groups of local students. This suggests that while the nonstrategic motives indeed matter for the decision in the Trust Game, the "business-like" setting of the game crowds-out the prosocial motivations present in the Triple Dictator Game.
} 
while abroad. Linking the results to different sources of discrimination, it seems that it is the statistical discrimination which emerges with increased international experience. There are four main arguments for such a claim:

First, students with study abroad experience start to differentiate between partners from Northern and Southern Europe in the Trust Game, in which the expected behavior of partners actually matters. On the contrary, students after a study abroad program do not discriminate based on a partner's nationality in the Triple Dictator Game, where expectations about a partners' behavior do not matter. Changes in observed behavior in the Trust-Game seem to be driven by the beliefs-based component of trust, as they persist even when controlling for the preference-based motives using the Triple Dictator Game.

Second, the way students with Erasmus experience differentiate between partners in the Trust Game is consistent with the variation in social capital across Europe. Southern Europe scores much lower in interpersonal trust than Northern Europe (see Figure 1). While Czech students with less international experience ("Before Erasmus") do not differentiate between Northern and Southern partners in the Trust Game, students after Erasmus study abroad show lower trust towards Southern partners, possibly because they learned about low social capital in the South.

Third, while the effect on behavior towards Southern partners goes in the same direction for students who went on a study abroad to Northern Europe, the effect is stronger among subjects with study abroad experience from Southern Europe, who are more likely to encounter behavioral differences in the South.

Fourth, the observed change in behavior in the Trust Game is accompanied by a change in beliefs regarding Northern and Southern partners, which were measured separately. 


\subsubsection{Behavior of foreigners}

The behavior and beliefs of subjects who returned from an Erasmus study abroad is consistent with the explanation that they learned about relatively lower social capital in Southern Europe while abroad. However, this may not correctly reflect the behavior of Northern and Southern subjects in my sample. The foreigners from Northern and Southern Europe who took part in the experiment-mostly Erasmus students studying in Prague - are not by any means a representative sample of students from these regions. The program is very selective in general. Moreover, these students chose to study in Prague.

In this subsection I examine whether Southern students in my sample $(\mathrm{N}=78)$ are less trustworthy than Northern students in my sample $(\mathrm{N}=45)$. I computed individual-level trustworthiness as the average return ratio (Return ratio= amount returned to sender $/\left(3^{*}\right.$ amount sent by sender $)$, averaging over all senders and all strategy method levels. I find that there is no significant difference in trustworthiness between individuals from the two regions. Northern receivers send back on average $21 \%$ of the amount received, while Southern receivers return on average $23 \%$ (Wilcoxon rank-sum test, $p=0.395) .{ }^{21}$

Focusing instead on trust behavior (calculated for each individual as the average amount sent across all partners), I find that Northern students are more trusting than Southern students, sending on average 55.1 vs. 48.4 points, but the difference is not statistically significant $(p=0.240)$. Interestingly, while Southern senders do not differentiate between Czech, Northern and Southern partners, Northern senders send significantly lower amounts to partners from Southern Europe, relative to Czech or Northern partners, see Appendix Table A.4.

\footnotetext{
${ }^{21}$ Separating the trustworthiness for different levels of senders' trust (sending 20, 40,60,80, or 100 points), Southern partners are relatively more trustworthy for low levels of senders' trust. They return on average $13 \%$ of the amount received if senders send 20 points, compared to $9 \%$ among Northern receivers $(p=0.132)$, and $20 \%$ vs. $16 \%$ if senders send 40 points, $(p=0.228)$.
} 
There are two main messages from this subsection. First, the behavior and beliefs of subjects "After Erasmus" seems to respond to relatively lower social capital in Southern Europe compared to Northern Europe. However, this heuristic is applied even to a very selected group of foreigners studying in Prague, among whom we do not observe significant differences in trust or trustworthiness behavior. Discrimination between Northern and Southern partners in the experiment can therefore be interpreted as statistical discrimination based on incorrect beliefs. Whether these beliefs would be correct for a representative sample of Northern and Southern students we do not know.

Second, the fact that Northern students in my sample also discriminate against Southern partners in the Trust Game suggests that the learning channel of international experience can go in two ways: i) students learn about behavioral differences in Southern Europe while abroad and ii) students learn how people from Northern Europe perceive Southern Europe while abroad.

\subsection{International experience and bias against foreigners}

After examining the learning channel of international experience, this section focuses on the change in preferences towards foreigners. The logic of the analysis performed here is different from that used in the previous section. The hypothesis is that the study-abroad experience leads to more favorable treatment of foreign partners, through creating affective ties or through strengthening a sense of common identity. Therefore, I no longer compare behavior towards Northern and Southern partners. Rather, I examine how students behaved towards their ingroup (partners of students' own nationality) and outgroup (partners of other nationalities) and whether the ingroup favoritism diminished with an Erasmus stay. The focus is on the behavior in the Triple Dictator Game - it provides a cleaner measure of non-strategic prosocial preferences, as the partner has only a passive role in this game. 


\subsubsection{Triple Dictator game - local vs. foreign partners}

Panel B of Table 3 presents the average amounts sent in the Dictator Game by the Erasmus status of the sender ("Before Erasmus" or "After Erasmus") and by whether the partner was local or foreign. The results show that there is only small and insignificant ingroup favoritism towards their own nationality for the students who were about to participate in the Erasmus program (Wilcoxon rank-sum test, $p=0.829$ ). Study-abroad experience then has a negative impact on the amount sent in the Triple Dictator Game, both when the partners are of the sender's own nationality $(p=0.075)$ and when they are of a different nationality $(p=0.004)$. The in-group favoritism among students "After Erasmus" is still rather small and insignificant $(p=0.154)$.

Estimation results presented in columns 1-3 of Table 7 confirm that the discrimination pattern between local and foreign partners does not change with Erasmus (as captured by the variable ReceiverForeign $*$ AfterErasmus). When controlling for other characteristics, subjects after an Erasmus stay sent lower amounts than subjects before Erasmus, but neither group significantly differentiates between local and foreign recipients. After disentangling between international partners from Northern and Southern Europe (columns 4-6 of Table 7), the results show that among students "Before Erasmus", there is a small significant bias against partners from Northern Europe, when controlling for other characteristics. Potentially, students "Before Erasmus" perceived partners from the North as wealthier and therefore less needy than other partners. 
Table 7: Outgroup bias against foreigners - Effects of an Erasmus study abroad

Dependent variable

Sample
Amount sent in the Triple DG Senders "Before Erasmus" and "After Erasmus"

(1)

(2)

(3)

(4)

(5)

(6)

After Erasmus

Receiver Foreign

$\begin{array}{ccc}-3.44 & -8.80^{* *} & -8.99^{* *} \\ (4.31) & (4.17) & (4.08) \\ -1.20 & -1.75 & -2.17 \\ (1.40) & (1.38) & (1.37) \\ -0.69 & 0.00 & 0.18 \\ (1.88) & (1.81) & (1.81)\end{array}$

Receiver North

Receiver South

Receiver North*After Erasmus

Receiver South*After Erasmus

\section{Constant}

$30.61 * * *$

Sender's gender, age, study major

Receiver's gender, age, study major

Order of the games, roles

\begin{tabular}{lrrrrrr} 
Observations & \multicolumn{3}{c}{ yes } & \multicolumn{3}{c}{ yes } \\
\hline \hline
\end{tabular}

Notes: OLS, standard errors are clustered on the sender level.* $\mathrm{p}<0.10, * * \mathrm{p}<0.05, * * * \mathrm{p}<0.01$. Estimation sample are (Czech and Slovak) subjects before and after Erasmus study abroad. Dummy variable "After Erasmus" is equal to one for subjects after and zero for those before Erasmus program. Dummy variable "Receiver Foreign" is equal to one if the receiver comes from abroad and zero for local receivers. See Table 2 for the classification of countries into "Local", "Foreign", "North" and "South". In columns 1-6, the omitted group are decisions of subjects "Before Erasmus" towards "Local" receivers. 
Overall, the results of this experiment do not support the hypothesis that international experience lessens negative attitudes towards foreigners. This is primarily because no preferential treatment of the subjects' own nationality was found for students prior to an Erasmus study abroad. If anything, then the ingroup favoritism is slightly greater for students with study-abroad experience.

Result 2: Erasmus study abroad stay does not change how students discriminate between local and foreign partners in the Triple Dictator Game. No outgroup bias against foreign partners was found and this result holds both for the students who are about to leave for their Erasmus stay, and for those who have already returned.

\subsubsection{Self-selection into studies abroad}

There are two possible explanations for Result 2. Either there is no ingroup favoritism towards their own nationality in the population of students, or those who self-select into going abroad already identify as "European", which is why they do not distinguish between partners of their own nationality and foreign partners. My results provide suggestive evidence for the latter argument.

To investigate the role of (self-) selection, I compare the behavior of students "Before Erasmus" to an auxiliary sample of 53 non-participants (the "Never Erasmus" sample). ${ }^{22}$ Estimation results are reported in Table 8. The "Never Erasmus" students differentiate more between local and foreign partners in the Triple Dictator Game than students "Before Erasmus". The outgroup bias is about twice the size and the null hypothesis of no outgroup bias can be rejected at the $5 \%$ level for the "Never Erasmus" students $(p=0.043)$, when controlling for other observable characteristics (columns 1-3).

Using data from the end-questionnaire, the "Never Erasmus" students are less

\footnotetext{
${ }^{22}$ The results should be perceived as suggestive evidence only, because I cannot claim that these students are a representative sample of all students who do not participate in the Erasmus program.
} 
Table 8: Outgroup bias against foreigners - Effects of an Erasmus study abroad vs. selection effect

\begin{tabular}{|c|c|c|c|}
\hline \multirow{2}{*}{$\begin{array}{l}\text { Dependent variable } \\
\text { Sample }\end{array}$} & \multicolumn{3}{|c|}{ Amount sent in the Triple DG } \\
\hline & $\begin{array}{c}\text { Senders } \\
\text { "Before } \\
\text { Erasmus" } \\
(1)\end{array}$ & $\begin{array}{c}\text { Senders } \\
\text { "After } \\
\text { Erasmus" } \\
(2) \\
\end{array}$ & $\begin{array}{c}\text { Senders } \\
\text { "Never } \\
\text { Erasmus" } \\
(3) \\
\end{array}$ \\
\hline Receiver Foreign & $\begin{array}{l}-1.67 \\
(1.32) \\
\end{array}$ & $\begin{array}{l}-1.84 \\
(1.31) \\
\end{array}$ & $\begin{array}{c}-3.74^{* *} \\
(1.81) \\
\end{array}$ \\
\hline Sender's gender, age, study major & yes & yes & yes \\
\hline Receivcer's gender, age, study major & yes & yes & yes \\
\hline Order of the games, roles & yes & yes & yes \\
\hline Observations & 1,111 & 1,834 & 781 \\
\hline \multicolumn{4}{|c|}{$\begin{array}{l}\text { Notes: OLS, standard errors are clustered on the sender level.* } \mathrm{p}<0.10,{ }^{* *} \mathrm{p}<0.05,{ }^{* * *} \\
\mathrm{p}<0.01 \text {. Estimation sample are all local (Czech and Slovak) subjects-before Erasmus } \\
\text { study abroad program ("Before Erasmus", column 1), After Erasmus study abroad ("Af } \\
\text { ter Erasmus", column 2) and program non-participants ("Never Erasmus", column 3) } \\
\text { Dummy variable "Receiver Foreign" is equal to one if the receiver comes from abroad and } \\
\text { zero for local receivers. See Table } 2 \text { for the classification of countries into "Local" and } \\
\text { "Foreign". In Columns 1-3, the omitted group are decisions towards "Local" receivers. }\end{array}$} \\
\hline
\end{tabular}

likely to identify themselves as part of the European Union, compared to students "After Erasmus" (58.6\% vs. $83.1 \% p=0.001$, Wilcoxon rank-sum test). If not taking selection into account, one could mistakenly conclude that international experience inspires students to identify more strongly as European. However, including the "Before Erasmus" students into the picture shows that there is a large and statistically significant difference between the non-participants and students who are about to participate in the program (58.6\% vs. $80 \%, p=0.009)$. The effect of the program - a difference between the "Before Erasmus" and "After Erasmus" students - is only small and statistically insignificant ( $80 \%$ vs. $83.1 \%$ who claim to feel they are members of the European Union, $p=0.197)$. This further highlights the advantages of the identification strategy used in this paper.

If one of the intentions of study-abroad programs is to create a sense of com- 
mon identity, the results of this research suggest that the programs should try to recruit more students and especially target those who feel less "international" to begin with. Also, it may be worthwhile to target younger students, as results from behavioral studies show that the most sensitive window for the formation of individual preferences and group-identity occurs at an earlier age-during childhood and adolescence (Almas, Cappelen, Sorensen, \& Tungodden, 2010; Bauer, Cassar, Chytilová, \& Henrich, 2014; Fehr, Rutzler, \& Sutter, 2011).

\section{Conclusion}

This paper examines whether attitudes toward other nationalities change with international experience. The variation in international experience was obtained by exploiting student participation in the Erasmus study-abroad program - the behavior of students who were about to participate in the program (75 students) was compared to that of students who had already completed their study abroad stay (124 students). Participants anonymously interacted with partners of different nationalities in a Trust Game and in a Triple Dictator Game. The Triple Dictator Game was used to control for a preference-based component of trust, helping to disentangle between statistical and taste-based discrimination.

I found the study-abroad experience affected behavior towards other nationalities, and specifically so in the Trust Game. While subjects prior to an Erasmus stay did not differentiate between partners from Northern and Southern Europe, subjects with study-abroad experience started to do so, exhibiting lower trust towards partners from the South. This result holds even when controlling for behavior in the Triple Dictator Game. Such a discrimination pattern is consistent with the lower rank of Southern countries in terms of general trust, as measured by the World Values Survey. As there is also an accompanying change in beliefs about cooper- 
ative behavior of partners from Southern Europe, the results overall support the hypothesis that people learn more about cross-country differences in social capital while abroad and subsequently change their behavior according to their experiences. Therefore, the results suggest that statistical discrimination towards different nationalities increases with international experience. This means that in a situation where there are differences in social capital across countries, globalization can create additional challenges for countries with lower social capital.

Examining next whether international experience changes preferences towards foreigners overall, I focused on behavior in the Triple Dictator Game and examined the strength of ingroup favoritism towards partners of a student's own nationality. The results show that even before their Erasmus stay abroad, senders do not show preferential treatment of partners coming from the same country, and preferences towards foreingers do not change with Erasmus. This suggests that the sense of group identity - national versus European - does not significantly shift with the program. Still, the Erasmus program is highly selective and the effects presented in this article should be understood as the average treatment effects on the treated. Students in my sample who do not plan to participate in the study abroad program show a significant bias against foreigners in the Triple Dictator Game and they feel less "European" than students who are ready to go abroad. There could be potential for the program to increase a sense of European identity, if it were able to target students who feel less "international" to begin with.

Overall, this paper confirms that individual attitudes towards people from other groups - nationalities in this case - can change simply by increased exposure to these groups. However, contrary to most studies on inter-group contact (Allport, 1954; Pettigrew, 1998; Pettigrew \& Tropp, 2006), I find that higher exposure leads to more discrimination. This seems to be driven by an increase in statistical discrimination, a channel which is not typically taken into account. 


\section{References}

Akerlof, G. A., \& Kranton, R. E. (2000). Economics and Identity. Quarterly Journal of Economics, 115(3), 715-753.

Alesina, A., \& La Ferrara, E. (2002). Who trusts others? Journal of Public Economics, 85(2), 207-234.

Allport, G. W. (1954). The nature of prejudice. Reading, MA: Addison Wesley.

Almas, I., Cappelen, A. W., Sorensen, E. O., \& Tungodden, B. (2010). Fairness and the development of inequality acceptance. Science, 328(5982), 1176-8.

Arrow, K. J. (1973). The Theory of Discrimination. In O. Ashenfelter \& A. Rees (Eds.), Discrimination in labor markets (pp. 3-33). Princeton University Press.

Arrow, K. J. (1998). What Has Economics to Say About Racial Discrimination? Journal of Economic Perspectives, 12(2), 91-100.

Bardsley, N. (2005). Experimental economics and the artificiality of alteration. Journal of Economic Methodology, 12(2), 239-251.

Bauer, M., Cassar, A., Chytilová, J., \& Henrich, J. (2014). War's enduring effects on the development of egalitarian motivations and in-group biases. Psychological Science, $25(1), 47-57$.

Bauer, M., Fiala, N., \& Levely, I. V. (2014). Trusting Former Rebels: An Experimental Approach to Understanding Reintegration after Civil War. CERGE-EI Working Paper Series, No. 512.

Beaman, L., Chattopadhyay, R., Duflo, E., Pande, R., \& Topalova, P. (2009). Powerful women: does exposure reduce bias? Quarterly Journal of Economics, $124(4), 1497-1540$.

Becker, G. S. (1971). The Economics of Discrimination. University of Chicago Press. 
Berg, J., Dickhaut, J., \& McCabe, K. (1995). Trust, Reciprocity, and Social History. Games and Economic Behavior, 10(1), 122-142.

Bernhard, H., Fehr, E., \& Fischbacher, U. (2006). Group Affiliation and Altruistic Norm Enforcement. American Economic Review, 96(2), 217-221.

Boisjoly, J., Duncan, G. J., Kremer, M., Levy, D. M., \& Eccles, J. (2006). Empathy or Antipathy? The Impact of Diversity. American Economic Review, 96(5), 1890-1905.

Bornhorst, F., Ichino, A., Kirchkamp, O., Schlag, K. H., \& Winter, E. (2010). Similarities and differences when building trust: the role of cultures. Experimental Economics, 13(3), 260-283.

Buchan, N. R., Johnson, E. J., \& Croson, R. T. A. (2006). Let's get personal: An international examination of the influence of communication, culture and social distance on other regarding preferences. Journal of Economic Behavior E Organization, 60(3), 373-398.

Charness, G., Rigotti, L., \& Rustichini, A. (2007). Individual Behavior and Group Membership. American Economic Review, 97(4), 1340-1352.

Chen, Y., \& Li, S. X. (2009). Group identity and social preferences. American Economic Review, 99(1), 431-457.

Clingingsmith, D., Khwaja, A. I., \& Kremer, M. (2009). Estimating the Impact of the Hajj: Religion and Tolerance in Islam's Global Gathering. Quarterly Journal of Economics, 124(3), 1133-1170.

Di Pietro, G. (2013). Do Study Abroad Programs Enhance the Do Study Abroad Programs Enhance the Employability of Graduates? IZA Disscussion Paper, 7675.

Dobbie, W., \& Fryer Jr., R. G. (2015). The Impact of Voluntary Youth Service on Future Outcomes: Evidence from Teach For America. The BE Journal of Economic Analysis \& Policy(forthcoming). 
European Commission. (2014). The Erasmus Impact Study: Effecs of mobility on the skills and employability of students and the internationalisation of higher education institutions. European Union.

Fehr, E., Rutzler, D., \& Sutter, M. (2011). The development of egalitarianism, altruism, spite and parochialism in childhood and adolescence. IZA Discussion Paper(5530).

Fershtman, C., \& Gneezy, U. (2001). Discrimination in a Segmented Society: An Experimental Approach. Quarterly Journal of Economics, 116(1), 351-377.

Fischbacher, U. (2007). Z-TREE: Zurich toolbox for ready-made economic experiments. Experimental Economics, 10(2), 171-178.

Gachter, S., \& Herrmann, B. (2011). The limits of self-governance when cooperators get punished: Experimental evidence from urban and rural Russia. European Economic Review, 55(2), 193-210.

Glaeser, E. L., Laibson, D. I., Scheinkman, J. A., \& Soutter, C. L. (2000). Measuring Trust. Quarterly Journal of Economics, 115(3), 811-846.

Goette, L., Huffman, D., \& Meier, S. (2006). The Impact of Group Membership on Cooperation and Norm Enforcement: Evidence usng Random Assignment to Real Social Groups. American Economic Review Papers and Proceedings, $96(2), 212-216$.

Gorodnichenko, Y., \& Roland, G. (2011). Which dimensions of culture matter for long-run growth? American Economic Review, 101(3), 492-498.

Guiso, L., Sapienya, P., \& Zingales, L. (2009). Cultural Biases in Economic Exchange. Quarterly Journal of Economics, 124(3), 1095-1131.

Henrich, J., Boyd, R., Bowles, S., Camerer, C., Fehr, E., Gintis, H., \& Mcelreath, R. (2001). In Search of Homo Economicus: Behavioral Experiments in 15 Small-Scale Societies. American Economic Review, 91(2), 73-78.

Henrich, J., Mcelreath, R., Barr, A., Ensminger, J., Barrett, C., Bolyanatz, A., 
... Ziker, J. (2006). Costly Punishment Across Human Societies. Science, 312(June), 1767-1770.

Herrmann, B., Thöni, C., \& Gächter, S. (2008). Antisocial Punishment across Societies. Science, 319(5868), 1362-7.

Holm, H. J., \& Danielson, A. (2005). Tropic Trust versus Nordic Trust: Experimental Evidence from Tanzania and Sweden. Economic Journal, 115(2005), $505-532$.

Knack, S., \& Keefer, P. (1997). Does Social Capital Have an Economic Payoff? A Cross-Country Investigation. Quarterly Journal of Economics, 112(4), 12511288.

Laar, C. V., Levin, S., Sinclair, S., \& Sidanius, J. (2005). The effect of university roommate contact on ethnic attitudes and behavior. Journal of Experimental Social Psychology, 41(4), 329-345.

Parey, M., \& Waldinger, F. (2010). Studying Abroad and the Effect on International Labour Market Mobility: Evidence from the Introduction of Erasmus. The Economic Journal, 121(March), 194-222.

Pettigrew, T. F. (1998). Intergroup contact theory. Annual review of psychology, $49,65-85$.

Pettigrew, T. F., \& Tropp, L. R. (2006). A meta-analytic test of intergroup contact theory. Journal of personality and social psychology, 90(5), 751-83.

Tabellini, G. (2010). Culture and Institutions: Economic Development in the Regions of Europe. Journal of the European Economic Association, 8(June), $677-716$.

Tajfel, H., Billing, M., Bundy, R., \& Flament, C. (1971). Social Categorization and Intergroup Behavior. European Journal of Social Psychology, 1(2), 149-178.

Willinger, M., Keser, C., Lohmann, C., \& Usunier, J.-C. (2003). A comparison of trust and reciprocity between France and Germany: Experimental investiga- 
tion based on the investment game. Journal of Economic Psychology, 24(4), $447-466$. 


\section{Appendix}

Figure A.1: Interpersonal trust across European countries

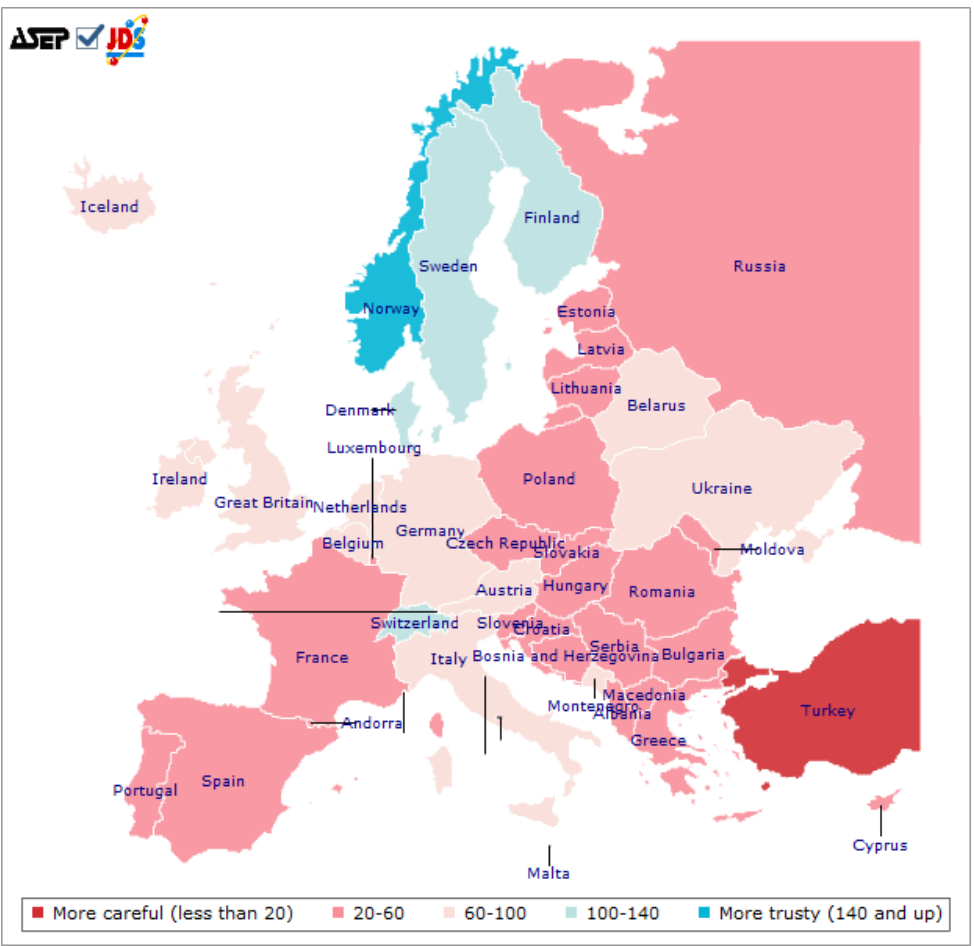

Notes: The Figure summarizes answers to the World Values Survey question "Generally speaking, would you say that most people can be trusted or that you need to be very careful in dealing with people?" (Source: ASEP/JDS) 
Figure A.2: Robustness check - Effects of Erasmus study abroad on behavior towards partners from Northern and Southern Europe, by the date of the experiment

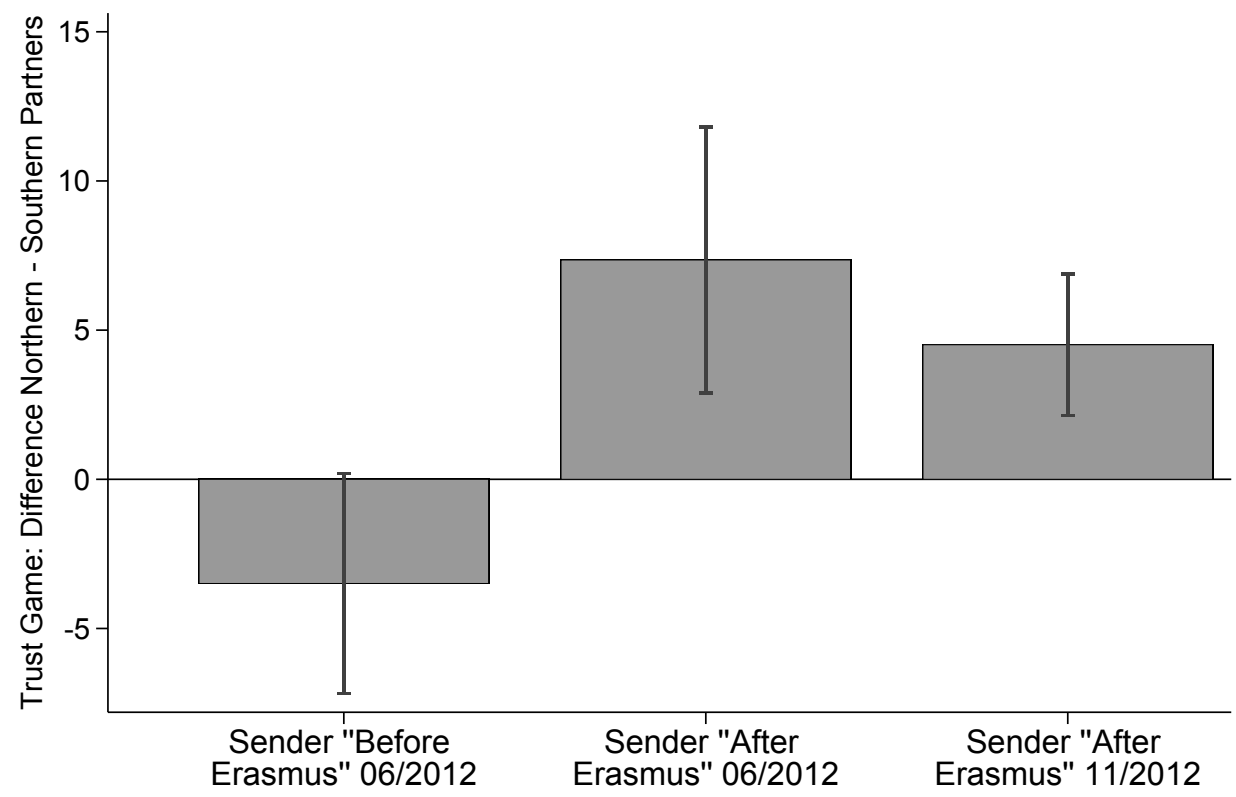

Notes: The Figure presents differences in behavior towards Nothern vs. Southern partners in the Trust Game, disentangled by whether the subjects are about to leave on a study abroad stay (Sender "Before Erasmus") or have just returned from a study abroad stay (Sender "After Erasmus") and by the time of the experiment (June 2012 vs. November 2012). See Table 2 for the classification of countries into "North" and "South". Bars indicate mean \pm standard error. 
Figure A.3: Correlation between individual trust and trustworthiness for all subjects in the experiment

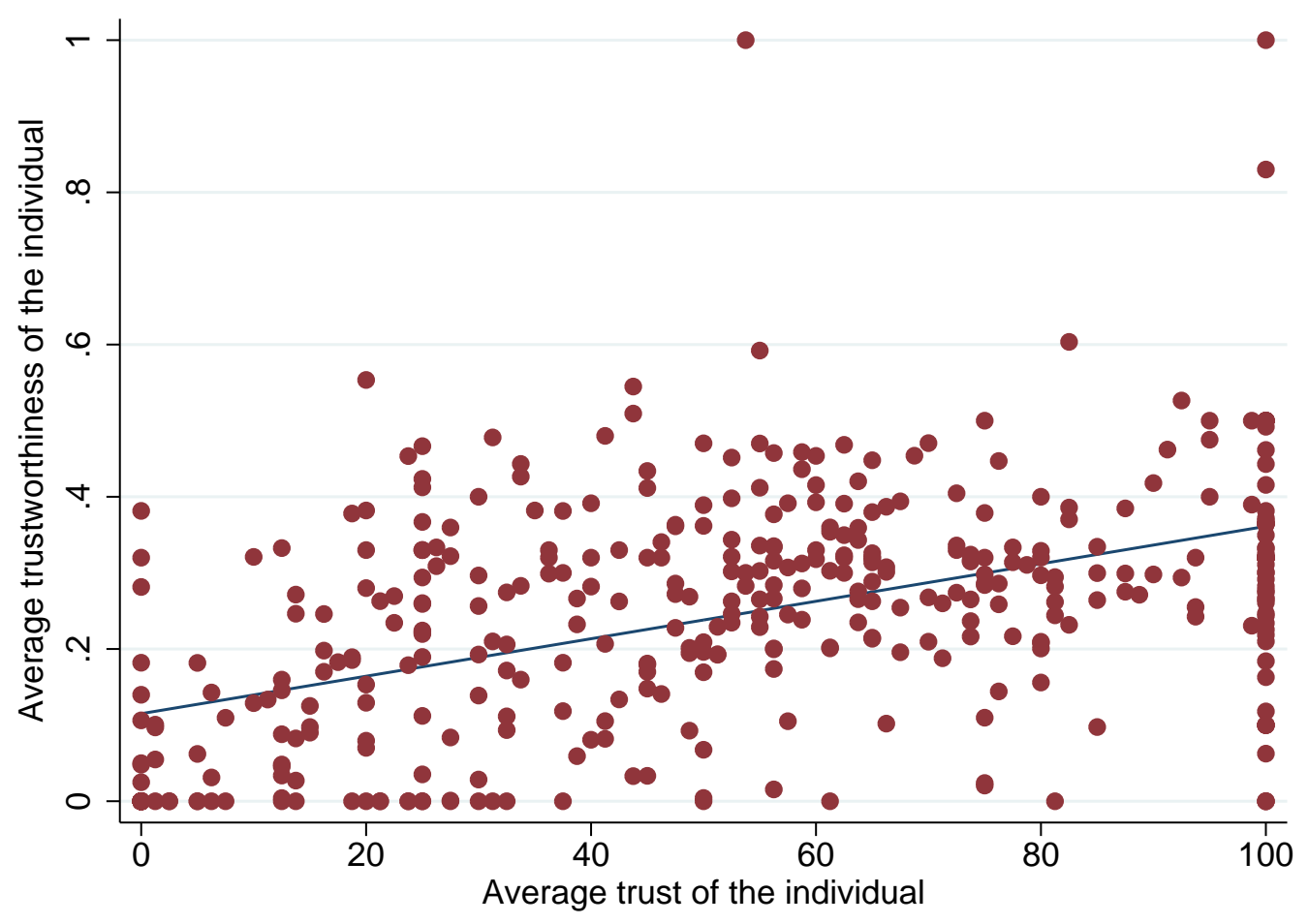

Notes: Average individual trust is calculated as the average amount sent in the Trust Game, averaging over the 16 profiles of potential partners. Average individual trustworthiness is calculated as average return ratio (Return ratio=amount returned to sender/( $3^{*}$ amount sent by sender $)$, averaging over all receiver's decisions. Each receiver made 80 trustworthiness decisions - there are 16 profiles of potential senders and 5 trustworthiness decisions per sender, as receivers' decisions were elicited using a strategy method. 
Table A.1: Recruitment into the experiment - all Charles University outbound Erasmus students vs. experiment participants

\begin{tabular}{|c|c|c|c|c|c|c|c|c|c|}
\hline & & & \multicolumn{2}{|c|}{$\begin{array}{l}\text { Database of outbound } \\
\text { Erasmus students }\end{array}$} & \multicolumn{2}{|c|}{$\begin{array}{l}\text { Experiment } \\
\text { participants }\end{array}$} & \multirow{2}{*}{$\begin{array}{c}\text { Difference } \\
\text { databases } \\
\text { diff }(2)-(1) \\
(5)\end{array}$} & \multicolumn{2}{|c|}{$\begin{array}{c}\text { Recruitment } \\
\text { into the experiment }\end{array}$} \\
\hline & & & $\begin{array}{c}2012 / 13 \\
(1)\end{array}$ & $\begin{array}{c}2011 / 12 \\
(2)\end{array}$ & $\begin{array}{c}2012 / 13 \\
(3)\end{array}$ & $\begin{array}{c}2011 / 12 \\
(4)\end{array}$ & & $\begin{array}{c}\operatorname{diff}(3)-(1) \\
(6)\end{array}$ & $\begin{array}{c}\operatorname{diff}(4)-(2) \\
(7)\end{array}$ \\
\hline Gender & Female & $\%$ & 69,7 & 69,9 & 61,3 & 56,8 & 0,2 & 8,3 & $13,1^{* * *}$ \\
\hline \multirow{2}{*}{ Study program } & $\mathrm{BA}$ & $\%$ & 38,1 & 28,1 & 49,3 & 33,9 & $-10,0^{* * *}$ & $-11,2^{*}$ & $-5,8$ \\
\hline & MA & $\%$ & 59,0 & 69,0 & 49,3 & 65,3 & $10,0^{* * *}$ & 9,7 & 3,7 \\
\hline \multirow[t]{5}{*}{ Field of study } & Business/Economics/Law & $\%$ & 14,8 & 17,2 & 17,3 & 22,9 & 2,4 & $-2,5$ & $-5,7$ \\
\hline & Humanities/Social sc./Education & $\%$ & 31,6 & 30,4 & 32,0 & 32,2 & $-1,2$ & $-0,4$ & $-1,8$ \\
\hline & Math/Physics/Natural sc./Technical & $\%$ & 15,6 & 15,0 & 16,0 & 18,6 & $-0,6$ & $-0,4$ & $-3,6$ \\
\hline & Medicine & $\%$ & 16,0 & 18,8 & 14,7 & 10,2 & 2,8 & 1,3 & $8,6^{* *}$ \\
\hline & Arts/Philosophy/Languages & $\%$ & 21,9 & 18,5 & 20,0 & 16,1 & $-3,4$ & 1,9 & 2,4 \\
\hline \multirow[t]{3}{*}{ Host Country } & North & $\%$ & 64,4 & 60,9 & 65,3 & 66,1 & $-3,5$ & $-0,9$ & $-5,2$ \\
\hline & South & $\%$ & 30,2 & 32,7 & 29,3 & 26,27 & 2,5 & 0,9 & 6,4 \\
\hline & New EU & $\%$ & 5,4 & 6,4 & 5,3 & 7,63 & 1,0 & 0,1 & $-1,2$ \\
\hline Participants & Total & $\mathrm{N}$ & 923 & 1009 & 75 & $\begin{array}{l}118 \\
\end{array}$ & 1932 & $\begin{array}{l}998 \\
\end{array}$ & 1127 \\
\hline
\end{tabular}

Notes: Means. "Before Erasmus" subjects were recruited from the 2012/13 database, "After Erasmus" subjects were recruited from the 2011/12 database. Six students from the "After Erasmus" sample were not students of Charles University or they participated in the Erasmus program prior to the academic year 2011/2012; that is why they are not included in this comparison. All differences are tested using a t-test, ${ }^{*} \mathrm{p}<0.10,{ }^{* *} \mathrm{p}<0.05$, *** $\mathrm{p}<0.01$. 
Table A.2: Trust Game - Effects of Erasmus study abroad on behavior towards partners from Northern and Southern Europe, ordered probit

\begin{tabular}{lcccccc}
\hline \hline & \multicolumn{7}{c}{ Marginal fixed effects after ordered probit } \\
Dependent variable & Probability of the Amount sent in the Trust Game being: \\
& 100 & 80 & 60 & 40 & 20 & 0 \\
Sample & \multicolumn{1}{c}{ Senders "Before Erasmus" and "After Erasmus" } \\
& $(1)$ & $(2)$ & $(3)$ & $(4)$ & $(5)$ & $(6)$ \\
\hline \multirow{2}{*}{ After Erasmus } & 0.010 & 0.001 & 0.000 & -0.001 & -0.002 & -0.008 \\
& $(0.053)$ & $(0.006)$ & $(0.000)$ & $(0.007)$ & $(0.011)$ & $(0.042)$ \\
Receiver South & 0.030 & 0.003 & -0.000 & -0.004 & -0.006 & -0.023 \\
& $(0.036)$ & $(0.004)$ & $(0.001)$ & $(0.005)$ & $(0.008)$ & $(0.028)$ \\
Receiver South*After Erasmus & $-0.080^{* *}$ & $-0.011^{*}$ & -0.002 & $0.010^{* *}$ & $0.016^{* *}$ & $0.066^{*}$ \\
& $(0.040)$ & $(0.006)$ & $(0.003)$ & $(0.005)$ & $(0.008)$ & $(0.035)$ \\
Observations & & & & & & \\
\hline \hline
\end{tabular}

Notes: Ordered probit, standard errors are clustered on the sender level.* $\mathrm{p}<0.10,{ }^{* *} \mathrm{p}<0.05$, $* * * \mathrm{p}<0.01$. Estimation sample are (Czech and Slovak) subjects before and after Erasmus study abroad. Dummy variable "After Erasmus" is equal to one for subjects after and zero for those before Erasmus program. Dummy variable "Receiver South" is equal to one if the receiver comes from Southern Europe and zero for receivers from Northern Europe. See Table 2 for the classification of countries into "North" and "South". In Columns 1-6, the omitted group are decisions of subjects "Before Erasmus" towards receivers from Northern Europe. 
Table A.3: Beliefs about trust - Effects of Erasmus study abroad on beliefs about behavior of Senders from Northern and Southern Europe

\begin{tabular}{|c|c|c|c|c|c|}
\hline \multirow{2}{*}{$\begin{array}{l}\text { Dependent variable } \\
\text { Sample }\end{array}$} & \multicolumn{5}{|c|}{ Beliefs about Amount sent in the Trust Game } \\
\hline & $\begin{array}{c}\text { Receiver } \\
\text { "Before Erasmus" } \\
\text { and "After Erasmus" } \\
(1)\end{array}$ & $\begin{array}{c}\text { Receiver } \\
\text { "Before } \\
\text { Erasmus" } \\
(2)\end{array}$ & $\begin{array}{l}\text { Receiver } \\
\text { "After } \\
\text { Erasmus" } \\
(3)\end{array}$ & \multicolumn{2}{|c|}{\begin{tabular}{|c|} 
Receiver \\
"Before Erasmus" \\
and "After Erasmus" \\
$(4)$
\end{tabular}} \\
\hline Receiver After Erasmus & $\begin{array}{c}1.54 \\
(4.73)\end{array}$ & & & $\begin{array}{l}-1.10 \\
(4.84)\end{array}$ & $\begin{array}{l}-1.45 \\
(4.87)\end{array}$ \\
\hline Sender South & $\begin{array}{l}5.78^{* *} \\
(2.81)\end{array}$ & $\begin{array}{l}5.78^{* *} \\
(2.82)\end{array}$ & $\begin{array}{c}-3.65^{* *} \\
(1.84)\end{array}$ & $\begin{array}{c}6.01^{* *} \\
(2.70)\end{array}$ & $\begin{array}{c}5.43^{* *} \\
(2.63)\end{array}$ \\
\hline Sender South*Receiver After Erasmus & $\begin{array}{c}-9.43^{* * *} \\
(3.35)\end{array}$ & & & $\begin{array}{c}-9.88^{* * *} \\
(3.33)\end{array}$ & $\begin{array}{c}-9.36^{* * * *} \\
(3.31)\end{array}$ \\
\hline Constant & $\begin{array}{c}54.22 \text { *** } \\
(3.83)\end{array}$ & $\begin{array}{c}54.22^{* * * *} \\
(3.85)\end{array}$ & $\begin{array}{c}55.76^{* * *} \\
(2.78)\end{array}$ & & \\
\hline Sender's gender, age, study major & & & & yes & yes \\
\hline Receivcer's gender, age, study major & & & & yes & $\begin{array}{l}\text { yes } \\
\text { ves }\end{array}$ \\
\hline Order of the games, roles & & & & & yes \\
\hline Observations & 1,512 & 523 & 989 & 1,512 & 1,512 \\
\hline $\begin{array}{l}\text { Notes: OLS, Standard errors are cluster } \\
\text { trust capture beliefs of receivers regardir } \\
\text { sample are (Czech and Slovak) subjects } \\
\text { Erasmus" is equal to one for subjects af } \\
\text { South" is equal to one if the sender com } \\
\text { See Table } 2 \text { for classification of countries } \\
\text { of subjects "Before Erasmus" regarding } \\
\text { group are beliefs regarding senders from }\end{array}$ & $\begin{array}{l}\text { d on the receiver level. } \\
\text { the amount sent to th } \\
\text { efore and after Erasmus } \\
\text { er and zero for those be } \\
\text { s from Southern Europe } \\
\text { nto "North" and "South } \\
\text { behavior of senders fron } \\
\text { Northern Europe. }\end{array}$ & $\begin{array}{l}\mathrm{p}<0.10,^{*} \\
\text { study by the } \mathrm{s} \\
\text { study } \\
\text { ore Erasmu } \\
\text { and zero fo } \\
\text { ". In colum } \\
\text { Northern }\end{array}$ & $\begin{array}{l}\mathrm{p}<0.05, * * \\
\text { nder in the } \\
\text { ad. Dummy } \\
\text { program. } \\
\text { the senders } \\
\text { is } 1,4,5 \text {, the } \\
\text { Lurope. In } \mathrm{c}\end{array}$ & $\begin{array}{l}* \mathrm{p}<0.01 . \\
\text { Trust Game } \\
\text { variable " } \mathrm{R} \\
\text { Jummy vari } \\
\text { from Nort } \\
\text { fmitted gro } \\
\text { olumns 2-3 }\end{array}$ & $\begin{array}{l}\text { 3eliefs about } \\
\text {. Estimation } \\
\text { eceiver After } \\
\text { able "Sender } \\
\text { hern Europe. } \\
\text { up are beliefs } \\
\text { the omitted }\end{array}$ \\
\hline
\end{tabular}


Table A.4: Trust Game - Behavior of foreign subjects from Northern and Southern Europe

\begin{tabular}{|c|c|c|c|c|c|c|}
\hline \multirow{2}{*}{$\begin{array}{l}\text { Dependent variable } \\
\text { Sample }\end{array}$} & \multicolumn{6}{|c|}{ Amount sent in the Trust Game } \\
\hline & $\begin{array}{l}\text { Foreigners } \\
\quad(1) \\
\end{array}$ & $\begin{array}{l}\text { from North } \\
\qquad(2) \\
\end{array}$ & $\begin{array}{l}\text { rn Europe } \\
(3)\end{array}$ & $\begin{array}{c}\text { Foreigner } \\
(4) \\
\end{array}$ & $\begin{array}{l}\text { from } S c \\
(5) \\
\end{array}$ & $\begin{array}{l}\text { ern Europe } \\
(6)\end{array}$ \\
\hline Receiver North & $\begin{array}{l}-0.06 \\
(2.76)\end{array}$ & $\begin{array}{c}0.72 \\
(2.54)\end{array}$ & $\begin{array}{c}0.85 \\
(2.55)\end{array}$ & $\begin{array}{l}-1.19 \\
(2.17)\end{array}$ & $\begin{array}{l}-1.26 \\
(2.50)\end{array}$ & $\begin{array}{l}-1.33 \\
(2.42)\end{array}$ \\
\hline Receiver South & $\begin{array}{c}-11.15^{* * *} \\
(3.16)\end{array}$ & $\begin{array}{c}-9.80^{* * *} \\
(3.61)\end{array}$ & $\begin{array}{c}-9.55^{* * *} \\
(3.44)\end{array}$ & $\begin{array}{c}1.40 \\
(3.22)\end{array}$ & $\begin{array}{c}0.76 \\
(3.48)\end{array}$ & $\begin{array}{c}0.91 \\
(3.42)\end{array}$ \\
\hline Constant & $\begin{array}{c}57.98^{* * *} \\
(4.84)\end{array}$ & & & $\begin{array}{c}48.31^{* * * *} \\
(3.75)\end{array}$ & & \\
\hline Sender's gender, age, study major & & yes & yes & & yes & yes \\
\hline Receiver's gender, age, study major & & yes & yes & & yes & yes \\
\hline Order of the games, roles & & & yes & & & yes \\
\hline Observations & 671 & 671 & 671 & 1,155 & 1,155 & 1,155 \\
\hline
\end{tabular}

Notes: OLS, standard errors are clustered on the sender level. ${ }^{*} \mathrm{p}<0.10,{ }^{* *} \mathrm{p}<0.05, * * * \mathrm{p}<0.01$. Estimation sample are foreign subjects from Northern Europe in Columns 1-3 and foreign subjects from Southern Europe in Columns 4-6. Dummy variable "Receiver North" is equal to one if the receiver comes from Northern Europe and zero otherwise and variable "Receiver South" is equal to one if the receiver comes from Southern Europe and zero otherwise. In Columns 1-6, the omitted group are decisions of foreign subjects towards "Local" receivers. See Table 2 for the classification of countries into "Local", "North" and "South". 


\begin{abstract}
Abstrakt
Každý rok se miliony lidí přestěhují do zahraničí za školou nebo za prací. Tento výzkum ukazuje, jak taková mezinárodní zkušenost mění preference a stereotypy týkající se jiných národností. Pro identifikaci změny využívám účast v programu Erasmus: studenti, kteří se chystají vycestovat do zahraničí jsou použiti jako kontrolní skupina pro studenty, kteří se z programu právě vrátili. Studenti se účastní ekonomického experimentu, kde se rozhodují ve Hře na důvěru (Trust Game) a ve Hře na diktátora (Triple Dictator Game), tak aby bylo možné oddělit změny ve statistické diskriminaci od změn v diskriminaci založené na preferencích. Výsledky ukazují, že zatímco studenti chystající se na program Erasmus nerozlišují ve Hře na důvěru mezi partnery ze severní a jižní Evropy, studenti, kteří se ze studia v zahraničí již vrátili, projevují méně důvěry k partnerům z jižní Evropy. Chování vůči jiným národnostem ve Hře na diktátora se s účastí v programu Erasmus nemění. Celkově výsledky naznačují, že studenti se během programu seznámí s rozdíly v kooperativním chování mezi jednotlivými regiony, a proto statistická diskriminace se zahraniční zkušeností vzroste.
\end{abstract}




\section{Working Paper Series}

ISSN 1211-3298

Registration No. (Ministry of Culture): E 19443

Individual researchers, as well as the on-line and printed versions of the CERGE-EI Working Papers (including their dissemination) were supported from institutional support RVO 67985998 from Economics Institute of the ASCR, v. v. i.

Specific research support and/or other grants the researchers/publications benefited from are acknowledged at the beginning of the Paper.

(c) Jana Cahlíková, 2015

All rights reserved. No part of this publication may be reproduced, stored in a retrieval system or transmitted in any form or by any means, electronic, mechanical or photocopying, recording, or otherwise without the prior permission of the publisher.

Published by

Charles University in Prague, Center for Economic Research and Graduate Education (CERGE) and

Economics Institute of the CAS, v. v. i. (EI)

CERGE-El, Politických vězňů 7, 11121 Prague 1, tel.: +420 224005 153, Czech Republic.

Printed by CERGE-EI, Prague

Subscription: CERGE-EI homepage: http://www.cerge-ei.cz

Phone: + 420224005153

Email: office@cerge-ei.cz

Web: http://www.cerge-ei.cz

Editor: Jan Zápal

The paper is available online at http://www.cerge-ei.cz/publications/working_papers/.

ISBN 978-80-7343-363-5 (Univerzita Karlova v Praze, Centrum pro ekonomický výzkum a doktorské studium)

ISBN 978-80-7344-367-2 (Národohospodářský ústav AV ČR, v. v. i.) 
CERGE-EI

P.O.BOX 882

Politických vězňů 7

11121 Praha 1

Czech Republic http://www.cerge-ei.cz 